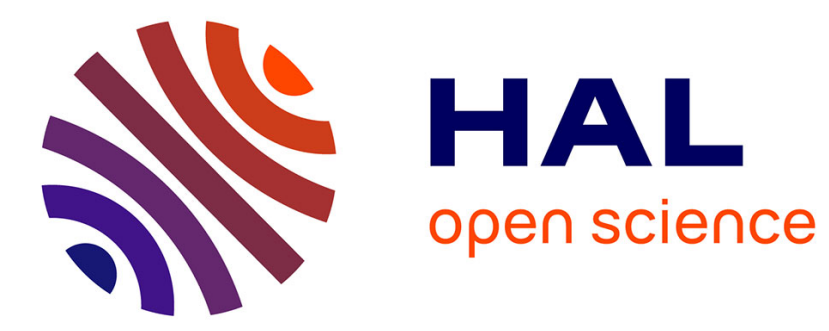

\title{
Impact of Climate Change on the Future Chemical Composition of the Global Troposphere
}

Guy Brasseur, Martin Schultz, Claire Granier, Marielle Saunois, Thomas Diehl, Michael Botzet, Erich Roeckner, Stacy Walters

\section{- To cite this version:}

Guy Brasseur, Martin Schultz, Claire Granier, Marielle Saunois, Thomas Diehl, et al.. Impact of Climate Change on the Future Chemical Composition of the Global Troposphere. Journal of Climate, 2006, 19 (16), pp.3932-3951. 10.1175/JCLI3832.1 . hal-00095625

\section{HAL Id: hal-00095625 \\ https://hal.science/hal-00095625}

Submitted on 2 May 2019

HAL is a multi-disciplinary open access archive for the deposit and dissemination of scientific research documents, whether they are published or not. The documents may come from teaching and research institutions in France or abroad, or from public or private research centers.
L'archive ouverte pluridisciplinaire HAL, est destinée au dépôt et à la diffusion de documents scientifiques de niveau recherche, publiés ou non, émanant des établissements d'enseignement et de recherche français ou étrangers, des laboratoires publics ou privés. 


\title{
Impact of Climate Change on the Future Chemical Composition of the Global Troposphere
}

\author{
Guy P. Brasseur,* Martin Schultz, Claire Granier, ${ }^{+}$Marielle Saunois, Thomas Diehl,\# \\ Michael Botzet, AND ERich RoecKner \\ Max Planck Institute for Meteorology, Hamburg, Germany \\ STACY WALTERS \\ National Center for Atmospheric Research, ${ }^{@}$ Boulder, Colorado
}

(Manuscript received 25 January 2005, in final form 27 September 2005)

\begin{abstract}
A global chemical transport model of the atmosphere [the Model for Ozone and Related Tracers, version 2 (MOZART-2)] driven by prescribed surface emissions and by meteorological fields provided by the ECHAM5/Max Planck Institute Ocean Model (MPI-OM-1) coupled atmosphere-ocean model is used to assess how expected climate changes (2100 versus 2000 periods) should affect the chemical composition of the troposphere. Calculations suggest that ozone changes resulting from climate change only are negative in a large fraction of the troposphere because of enhanced photochemical destruction by water vapor. In the Tropics, increased lightning activity should lead to larger ozone concentrations. The magnitude of the climate-induced ozone changes in the troposphere remains smaller than the changes produced by enhanced anthropogenic emissions when the Special Report on Emission Scenarios (SRES) A2P is adopted to describe the future evolution of these emissions. Predictions depend strongly on future trends in atmospheric methane levels, which are not well established. Changes in the emissions of NOx by bacteria in soils and of nonmethane hydrocarbons by vegetation associated with climate change could have a significant impact on future ozone levels.
\end{abstract}

\section{Introduction}

The chemical composition of the atmosphere has been changing substantially during the twentieth century in response to human activities. It is well known, for example, that the concentration of greenhouse gases has increased dramatically since the beginning of the industrial revolution. The atmospheric abundance

\footnotetext{
* Current affiliation: National Center for Atmospheric Research, Boulder, Colorado.

+ Additional affiliation: Service d'Aéronomie/IPSL, Paris, France, and Aeronomy Laboratory, NOAA-CIRES, Boulder, Colorado.

\# Current affiliation: NASA Goddard Space Flight Center, Greenbelt, Maryland.

@ The National Center for Atmospheric Research is sponsored by the National Science Foundation.
}

Corresponding author address: Guy P. Brasseur, National Center for Atmospheric Research, P.O. Box 3000, Boulder, CO 80307.

E-mail: brasseur@ucar.edu of reactive gases, specifically of tropospheric ozone, has also been considerably perturbed, primarily through intense emissions of combustion products such as carbon monoxide, nitrogen oxides, and volatile organic compounds, specifically in industrialized regions, where large amounts of fossil fuel are burnt, and in the Tropics, where biomass burning is frequent. The rapid increase in the methane concentration, in response to agricultural activities, has also contributed to enhanced ozone levels in the troposphere. The magnitude of the preindustrial level of ozone is not accurately established. Early observations made with the widely used Schönbein paper (a test paper impregnated with a mixture of potassium iodide and starch, and exposed to the air for several hours) suggest that the surface ozone mixing ratio was as low as 5-20 ppbv at the end of the nineteenth century (Volz and Kley 1988; Anfossi et al. 1991) in most parts of the world, even in continental regions like Europe. However, as highlighted by Pavelin et al. (1999), the measurements made using Schönbein's method were contaminated by the presence of water vapor, and uncertainties in the humidity correc- 
tion have led to considerable inaccuracies in these ozone measurements. Ozone is a greenhouse gas and a powerful oxidant. As a precursor of the hydroxyl $(\mathrm{OH})$ radical, it strongly influences the photochemical lifetime of many compounds and hence affects the selfcleaning ability (or oxidizing power) of the atmosphere.

Several studies using chemical transport models (see, e.g., Lelieveld and van Dorland 1995; Berntsen et al. 1997, 2000; Brasseur et al. 1998; Wang and Jacob 1998; Stevenson et al. 1998; Mickley et al. 1999; Shindell et al. 2001, 2003; Hauglustaine and Brasseur 2001; Lamarque et al. 2005) have estimated the changes in the concentration of tropospheric ozone and the related radiative forcing since the preindustrial era in response to changing emissions of chemical compounds. Model results are summarized in a report recently published by the European Commission (2003). These models have also been used to predict possible future changes based on preestablished emission scenarios (see e.g., van Dorland et al. 1997; Stevenson et al. 1998, 2000, 2005; Brasseur et al. 1998; Hauglustaine and Brasseur 2001; Grewe et al. 2001; Prather et al. 2003; Gauss et al. 2003). Several of these models (Stevenson et al. 2000, 2005; Grewe et al. 2001; Zeng and Pyle 2003; Murazaki and Hess 2006) have considered several potential feedback mechanisms linking future climate changes and ozone, specifically perturbations in the atmospheric circulation, temperature, water vapor concentration, cloudiness, etc.

The purpose of the present study is to assess the impact of predicted climate change on the future concentration of reactive gases in the troposphere, and to compare these climate-generated effects on the atmospheric composition with changes resulting directly from increasing chemical emissions. The goal is not to investigate in detail several possible scenarios, based on plausible economic futures, but to show through some specific model sensitivity cases the potential importance of future climate change, when predicting the response of the atmosphere to enhanced surface emissions.

In section 2, we briefly describe the modeling system used in the present study, and in section 3, we present the scenarios adapted to drive the model simulations. In section 4, we analyze and discuss the model results and assess the respective effects of climate change and increased surface emissions on the future chemical composition of the global troposphere. Conclusions are presented in section 5 .

\section{Description of the model system}

To assess the impact of future climate changes on the chemical composition of the atmosphere, we use a chemical transport model, the Model for Ozone and Related Tracers, version 2 (MOZART-2), which is driven by meteorological fields provided by a threedimensional climate model. This climate model simulates the coupled atmosphere-ocean-ice system and is forced by a $1 \% \mathrm{yr}^{-1}$ increase in the "effective" atmospheric $\mathrm{CO}_{2}$ concentration. The so-called effective $\mathrm{CO}_{2}$ is assumed to provide a radiative forcing that implicitly includes the contributions of all well-mixed greenhouse gases released to the atmosphere as a result of human activities.

The atmospheric component of the coupled climate model is ECHAM5, the latest version of the ECHAM model (Roeckner et al. 2003, 2006). It is run at T42 spectral resolution, which corresponds to a horizontal resolution of about $2.8^{\circ} \times 2.8^{\circ}$ and employs 19 layers in the vertical with the uppermost level located at $10 \mathrm{hPa}$. The ocean component of the model system is the Max Planck Institute Ocean Model (MPI-OM-1; Marsland et al. 2003). This model component is based on a C-grid version of the Hamburg Ocean Model in Primitive Equations (HOPE) run on a curvilinear grid with equatorial refinement $(\sim 10-50 \mathrm{~km}$ at high latitudes and near the equator). A Hibler-type dynamic/thermodynamic sea ice model and a river runoff scheme are included in the coupled model. The coupled atmosphere-ocean model does not employ flux adjustments or any other corrections. First results from a 250-yr control experiment are discussed by Latif et al. (2004).

The atmospheric dynamical fields provided by the coupled ECHAM-5/MPI-OM-1 model are archived for a period of $10 \mathrm{yr}$ corresponding approximately to present-time levels of $\mathrm{CO}_{2}(370 \mathrm{ppmv})$ and to twice this value (740 ppmv), respectively. The second case is assumed to be representative of the climate to be expected around year 2100 .

The chemical transport model used to simulate the chemical composition of the troposphere and the lower stratosphere is the MOZART-2 model, which is described in detail by Horowitz et al. (2003). The model (version 2.1) is integrated on a grid at a latitudinal and longitudinal resolution of $2.8^{\circ}$ and with 19 levels in the vertical up to $10 \mathrm{hPa}$. It includes a chemical scheme for the ozone/nitrogen oxides/hydrocarbon system that involves 63 species and 170 reactions. The chemical system is solved with a 20-min time step, using a fully implicit Euler backward method with NewtonRaphson iteration. As indicated by Horowitz et al. (2003), the concentrations of several compounds including ozone, nitrogen oxides, and nitric acid are constrained above the thermal tropopause by relaxation toward specified zonally and monthly averaged values (relaxation time constant of 10 days). With this model 
TABLE 1. Scenarios considered in the present study.

\begin{tabular}{|c|c|c|c|c|c|c|c|}
\hline Case & $\begin{array}{c}\text { Year for } \\
\text { anthropogenic } \\
\text { emissions }\end{array}$ & $\begin{array}{c}\text { Aircraft } \\
\text { emissions } \\
\left(\mathrm{TgN} \mathrm{yr}^{-1}\right)\end{array}$ & $\begin{array}{l}\text { Methane } \\
\text { (ppmv) }\end{array}$ & Other emissions & Climate & $\begin{array}{l}\text { Calculated } \\
\text { tropospheric } \\
\mathrm{O}_{3} \text { column } \\
\text { (DU) }\end{array}$ & Remarks \\
\hline A & 2000 & 0.7 & 1.7 & Baseline & $1 \times \mathrm{CO}_{2}$ & 29.75 & Baseline (reference) case \\
\hline $\mathrm{P}$ & 1890 & None & 0.85 & Baseline & $1 \times \mathrm{CO}_{2}$ & 20.59 & Preindustrial (1890) \\
\hline B & 2000 & 0.7 & 1.7 & Baseline & $2 \times \mathrm{CO}_{2}$ & 31.31 & $\begin{array}{l}\text { Baseline with future climate } \\
\text { (2100) }\end{array}$ \\
\hline $\mathrm{C}$ & 2100 & 0.7 & 3.6 & Baseline & $1 \times \mathrm{CO}_{2}$ & & $\begin{array}{l}\text { Future scenario with present } \\
\text { climate }\end{array}$ \\
\hline $\mathrm{D}$ & 2100 & 2.92 & 3.6 & Baseline & $1 \times \mathrm{CO}_{2}$ & 43.72 & $\begin{array}{l}\text { Same as } \mathrm{C} \text {, but with increased } \\
\text { aircraft emissions }\end{array}$ \\
\hline $\mathrm{E}$ & 2100 & 2.92 & 3.6 & Baseline & $2 \times \mathrm{CO}_{2}$ & 44.34 & $\begin{array}{l}\text { Future scenario with future } \\
\text { climate }\end{array}$ \\
\hline $\mathrm{F}$ & 2100 & 2.92 & 1.7 & Baseline & $2 \times \mathrm{CO}_{2}$ & 39.49 & $\begin{array}{l}\text { Methane does not increase in the } \\
\text { future }\end{array}$ \\
\hline G & 2100 & 2.92 & 3.6 & $\begin{array}{l}\text { Isoprene and soil NO } \\
\text { emissions } \times 2\end{array}$ & $2 \times \mathrm{CO}_{2}$ & 46.62 & $\begin{array}{l}\text { Impact of climatically changed } \\
\text { vegetation and soil emissions }\end{array}$ \\
\hline $\mathrm{H}$ & 2100 & 2.92 & 3.6 & Biomass burning $\times 2$ & $2 \times \mathrm{CO}_{2}$ & 41.88 & $\begin{array}{l}\text { Impact of biomass burning } \\
\text { changes }\end{array}$ \\
\hline
\end{tabular}

setup, the accuracy of the calculated changes in crosstropopause fluxes is limited. More reliable results should be obtained from a model such as MOZART-3 (Kinnison et al. 2006, manuscript submitted to J. Geophys. Res.) in which the concentrations of all chemical species are calculated in the middle atmosphere. Surface emissions include fossil fuel combustion, biomass burning, biogenic processes related to vegetation and soils, and exchanges with the ocean. NOx production by lightning is distributed depending on the location of convective clouds as diagnosed by MOZART-2. The flash frequency is estimated according to Price and Rind (1993). Tracer advection is performed using the flux form semi-Lagrangian finite-volume algorithm developed by Lin and Rood (1996). Convective transport is based on the parameterization of Zhang and McFarland (1995) for deep convection and of Hack (1994) for shallow convection. Vertical exchanges in the boundary layer are parameterized according to Holtslag and Boville (1993). Advection, convective transport, boundary layer mixing, cloudiness, and precipitation as well as wet and dry deposition, are derived in MOZART-2, using the formulations adopted in the Model for Atmospheric Transport and Chemistry (MATCH; Rasch et al. 1997) with input variables (zonal and meridional winds, temperature, specific humidity, surface pressure, and surface fluxes of heat and momentum) provided by the ECHAM model with a time interval of $6 \mathrm{~h}$. Note therefore that the representation of unresolved physical processes in MOZART is not entirely consistent with the formulation of the same processes adopted in the ECHAM model. It should also be realized that the model setting adopted here is not providing a full twoway coupling between atmospheric dynamics and chemistry because the calculated distributions of radiatively active species like ozone calculated by MOZART do not feed back into ECHAM. The one-way coupling realized in the present study allows us, however, to isolate specific processes, perform sensitivity tests, and hence understand the nature and magnitude of the coupling. But by adopting this approach, it is therefore assumed that tropospheric ozone has little influence on climate compared to other effects (water feedback, aerosol/cloud effects, etc.).

The atmospheric distributions of chemical species provided by MOZART-2 were evaluated in detail in the study by Horowitz et al. (2003). This paper shows that the distributions of most chemical species are well reproduced by the model with a few limited exceptions. For example, MOZART-2 tends to overestimate the concentration of ozone and peroxyacetyl nitrate (PAN) near the tropopause at higher northern latitudes, and to underestimate the concentration of carbon monoxide at some observation sites of the Northern Hemisphere.

\section{Scenarios}

To assess the impact of increasing emissions of chemical compounds and of climate changes on the chemical composition of the atmosphere, we consider nine different cases (Table 1). For each of them, the MOZART model is integrated for a period of $10 \mathrm{yr}$. The first year is discarded to allow for the spinup of the model. The 9-yr average fields are computed for each month of the year. 
TABLE 2. Emissions for preindustrial, present, and future conditions adopted in the model.

\begin{tabular}{|c|c|c|c|c|c|}
\hline Year & Anthropogenic & $\begin{array}{l}\text { Biomass } \\
\text { burning }\end{array}$ & $\begin{array}{l}\text { Biogenic } \\
\text { emissions }\end{array}$ & Oceans & Total \\
\hline \multicolumn{6}{|c|}{$\mathrm{CO}\left(\mathrm{TgCO} \mathrm{yr}^{-1}\right)$} \\
\hline 1890 & 84 & 65 & 160 & 20 & 329 \\
\hline 2000 & 650 & 337 & 160 & 20 & 1167 \\
\hline 2100 & 1680 & 337 & 160 & 20 & 2197 \\
\hline \multicolumn{6}{|c|}{ NOx $\left(\mathrm{TgN}_{\mathrm{yr}}^{-1}\right)$} \\
\hline 1890 & 1.5 & 1.4 & 2.9 & - & 6.8 \\
\hline 2000 & 31.8 & 6.2 & 8 & - & 46.0 \\
\hline 2100 & 109.0 & 6.2 & 8 & - & 123.2 \\
\hline \multicolumn{6}{|c|}{ 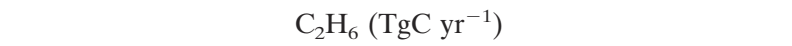 } \\
\hline 1890 & 0.5 & 0.3 & 0.8 & 0.8 & 2.4 \\
\hline 2000 & 5.5 & 2.0 & 0.8 & 0.8 & 9.1 \\
\hline 2100 & 11.0 & 2.0 & 0.8 & 0.8 & 14.6 \\
\hline \multicolumn{6}{|c|}{$\mathrm{C}_{2} \mathrm{H}_{4}\left(\mathrm{TgC} \mathrm{yr}^{-1}\right)$} \\
\hline 1890 & 1.1 & 0.7 & 4.3 & 1.2 & 7.2 \\
\hline 2000 & 3.9 & 4.1 & 4.3 & 1.2 & 13.5 \\
\hline 2100 & 7.8 & 4.1 & 4.3 & 1.2 & 17.4 \\
\hline
\end{tabular}

Case A, the baseline case, refers to the current atmosphere (approximately year 2000) and is used as the reference case. The emissions of chemical compounds are those adopted in Houghton et al. (2001) and described in the paper by Prather et al. (2003) and Gauss et al. (2003). The corresponding global emissions of CO and NOx are listed in Table 2. The tropospheric mean mixing ratio of methane is approximately $1.7 \mathrm{ppmv}$ with surface values fixed as monthly averages based on observations (GLOBALVIEW-CH4 2001).

In simulation $\mathrm{P}$, the emissions of chemical compounds are scaled to be representative of the preindustrial era (year 1890). Natural emissions are identical to those adopted for the present-day simulations. In the case of anthropogenic contributions, the emissions related to road and nonroad traffic are assumed to be zero, while industrial emissions are specified as $15 \%$ of the present-day values (same spatial distribution). This assumption accounts for the fact that industrialization started before 1890 in several countries of the Northern Hemisphere. Biomass burning emissions, which are often related to human activities, are prescribed to be $20 \%$ of the present emissions in the case of savanna fires, and they are equal to zero in the case of tropical forest fires (since deforestation was not prominent at that time). Emissions associated with forest fires at midand high latitudes, which are partly of human origin, are assumed to be a factor of 2 lower than present emissions. The level of methane adopted for the 1890 simulation is equal to $0.85 \mathrm{ppmv}$. Note, that for this particular scenario, the dynamics of the atmosphere provided by the ECHAM-5/OM-1 model is the same as in case $\mathrm{A}$.
In case $\mathrm{B}$, the emissions are identical to those model run $\mathrm{A}$, but the climate as derived from the ECHAM5/OM-1 model corresponds to a situation representative of a 10-yr period close to year 2100. This specific case allows us to isolate the effect of expected climate change (change in temperature, water vapor abundance, convective activity, lightning distribution and frequency, and precipitation rate) on the chemical composition.

In case $\mathrm{C}$, the surface emissions are modified to be representative of year 2100 on the basis of the $\mathrm{A} 2 \mathrm{P}$ scenario used in Houghton et al. (2001). This scenario is an adaptation for reactive species of the A2 scenario developed by the Special Report on Emission Scenarios (SRES) for greenhouse gases (I. S. A. Isaksen 2005, personal communication). The A2 scenario corresponds to a very heterogeneous world in which cooperation between the different countries is limited, and progress toward clean technologies is slow. The world population increases rapidly to reach 15 billion in year 2100 , and the income per capita is lower than in the other SRES scenarios. In case $\mathrm{C}$, the emissions from aircraft engines remain unchanged from the reference level (year 2000), and the climate variables are those of the baseline case (year 2000). The A2P scenario, which provides considerable perturbations, is adopted here not because it represents the most probable case, but because it facilitates the identification of the potentially important processes that link climate changes and air quality at the global scale. Figure 1 shows the total emissions of $\mathrm{CO}$ and $\mathrm{NOx}$ established on a $1^{\circ} \times 1^{\circ}$ grid for years 1890, 2000, and 2100, respectively. The regions most affected by changes in the emissions are Europe and North America for the 1890-2000 period, and Asia and South America for the 2000-2100 period. Under the adopted scenario, the anthropogenic emissions of CO increase by a factor of 8 between 1890 and 2000 and 2.5 between 2000 and 2100 . The corresponding values for the NOx increase are 16 and 3, respectively. Biomass burning emissions are assumed to be unchanged after year 2000.

Case D is identical to case C, but with enhanced aircraft emissions. As no reliable predictions for these emissions exist for year 2100, the values adopted here are those of year 2000 multiplied by a factor of 4 , with the same spatial distribution as present day. Under these assumptions, the total NOx emission by aircraft represents $2.9 \mathrm{Tg} \mathrm{yr}^{-1}$ against $0.7 \mathrm{TgN} \mathrm{yr}^{-1}$ under baseline conditions. More accurate information would require reliable estimates of the aircraft fleet size, the type of engines, and the extent and geographical distribution of fleet operations to be expected in year 2100. The values adopted here provide no more than a crude way to 
$\mathrm{CO}$
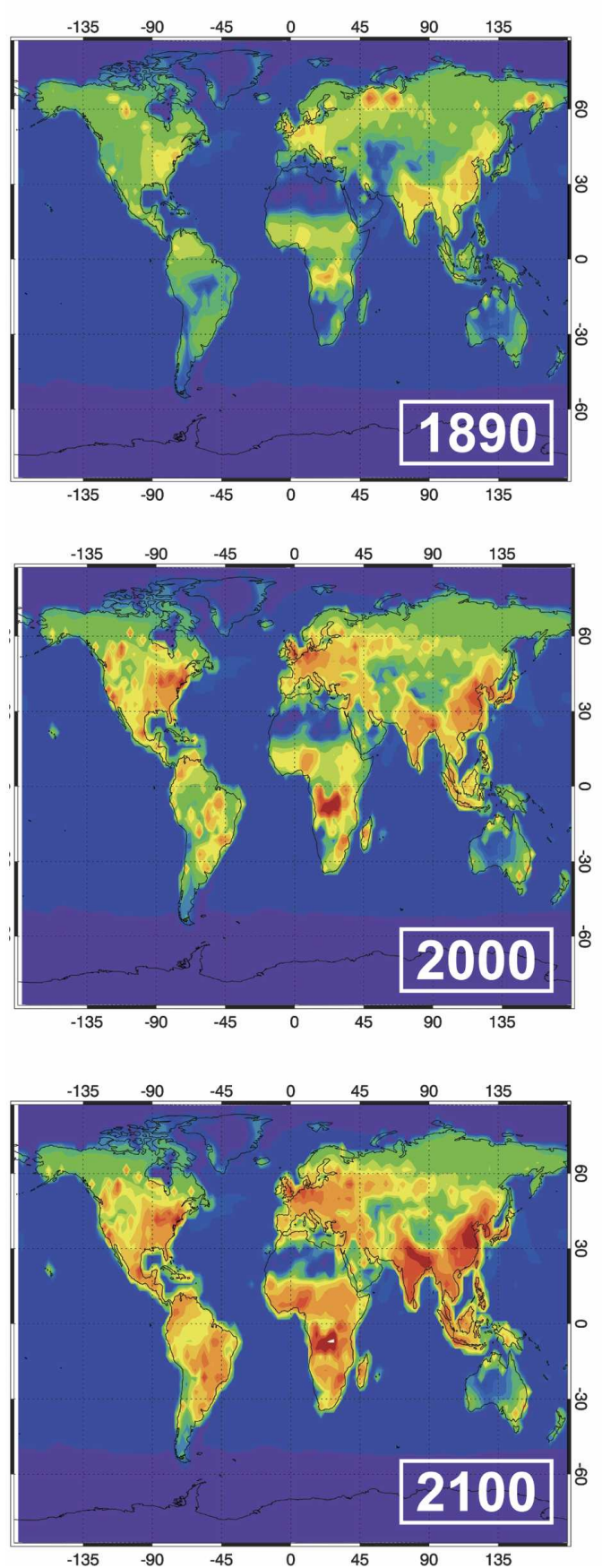

$\mathrm{NOx}$
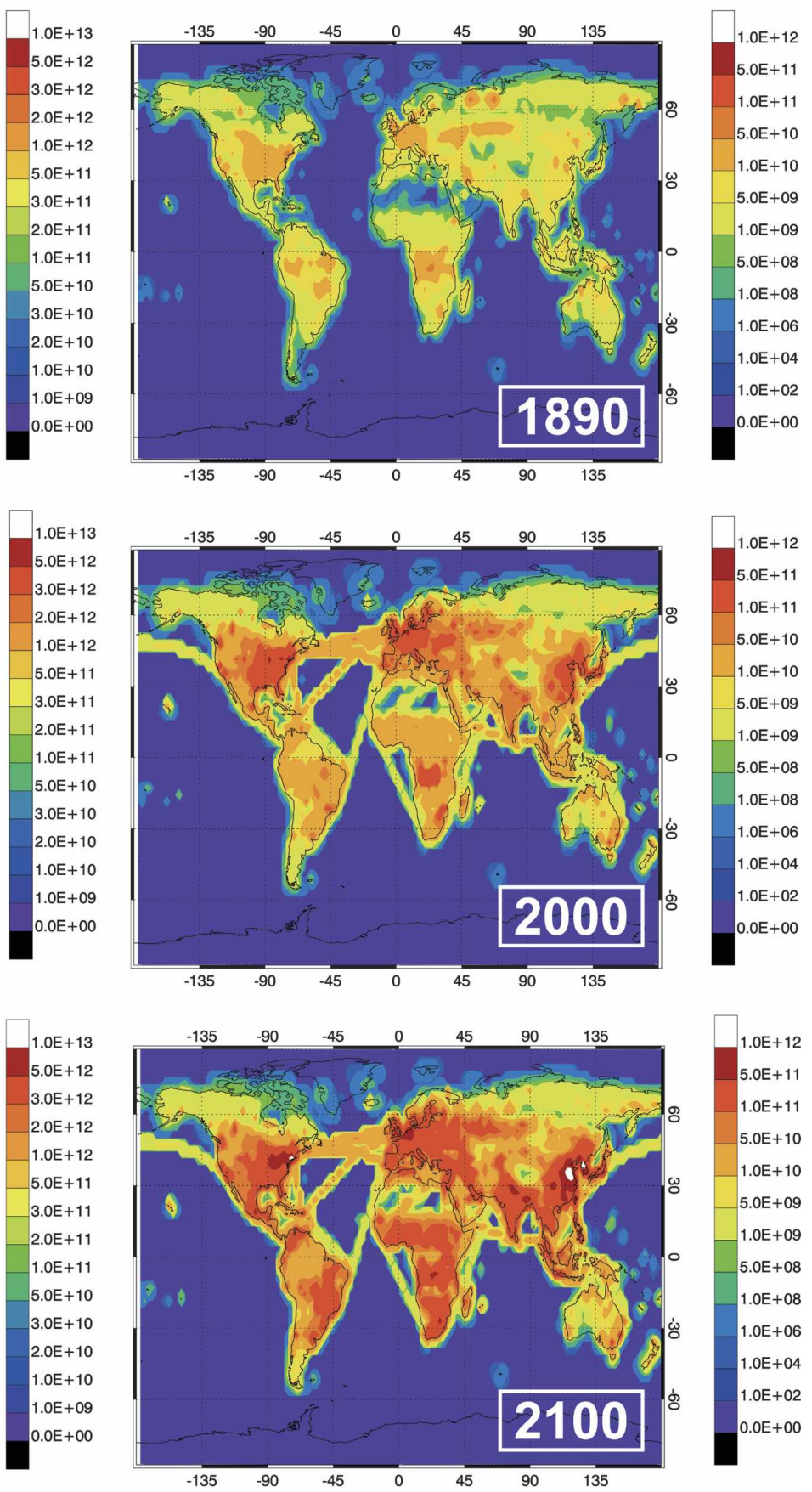

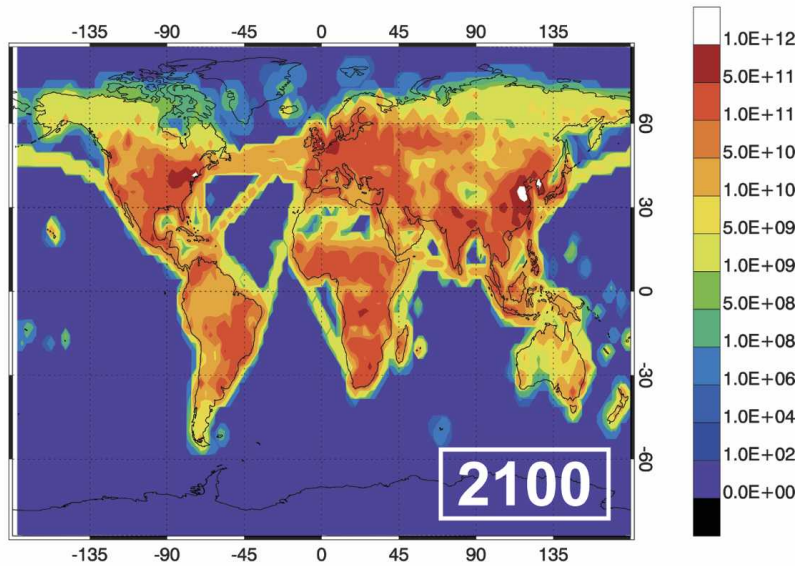

$\begin{array}{lllllll}-135 & -90 & -45 & 0 & 45 & 90 & 135\end{array}$

FIG. 1. Surface emissions $\left(\mathrm{cm}^{-2} \mathrm{~s}^{-1}\right)$ of carbon monoxide (CO) and nitrogen oxides (NOx) in July corresponding to the years (left) 1890, (middle) 2000, and (right) 2100, respectively.

assess the sensitivity of enhanced aircraft operations on the concentration of tropospheric trace species.

Case E corresponds to the same situation as case D (2100 emissions), but with climate conditions representative of year 2100 (doubled equivalent $\mathrm{CO}_{2}$ level). Thus, case $\mathrm{E}$ accounts simultaneously for the impacts of future anthropogenic emissions under scenario A2P and for the climate change calculated for a period around year 2100 by the Hamburg Climate System Model.

A major uncertainty in the prediction of the atmospheric composition is the future trend in the methane 
concentrations. During the 1980s, trends of typically $1 \% \mathrm{yr}^{-1}$ were reported on the basis of surface observations (Dlugokencky et al. 1994). The trends have been substantially lower in the 1990s and have even become insignificant in the last years. The changes in observed trends are not fully explained at present, so that any prediction for the future is difficult. Based on the adopted scenario, the mixing ratio of methane should reach approximately 3.6 ppmv (global average surface value), which is slightly more than a factor of 2 increase compared to the year 2000 values (average of $1.7 \mathrm{ppmv}$ ). To assess the importance of this uncertainty, we have also considered a "minimum" case (case F), in which the methane abundance remains at the year 2000 level, while all other forcings are similar to case E (including a doubling in the atmospheric concentration of equivalent $\mathrm{CO}_{2}$ ).

Finally, we have investigated the impact of other potential changes, which could result from climate changes and are not accounted for in the previous model runs. In case $G$, we make a sensitivity test to account for climate-driven changes in the temperaturedependent emissions of isoprene by vegetation and of nitrogen oxides by soils. These potential indirect effects are not yet well quantified. Therefore, in this particular model case, the isoprene and soil NOx emissions have been uniformly doubled in year 2100. Ongoing work suggests that this factor may not be unrealistic in the case of isoprene emissions (C. Wiedinmyer et al. 2005, personal communication). In the case of soil $\mathrm{NO}$, Yienger and Levy (1995) indicate that the emissions are increasing with temperature, especially in the case of wet soils. More detailed work is needed to provide more accurate estimates as well as the geographical and seasonal dependence of these expected changes. Other imposed changes are the same as those adopted in case E.

The consequences of future climate changes on wildfires are currently unknown, but could be substantial. The vulnerability of the forests to fires could increase in a warmer climate, although this effect may be transient and different in different parts of the world. In case $\mathrm{H}$, we performed a sensitivity test in which the emissions by biomass burning are increased uniformly by a factor of 2 , while the other forcing parameters are identical to those adopted in case E.

\section{Model results}

\section{a. The baseline case (A)}

To evaluate the global distributions of reactive gases provided by the MOZART-ECHAM-OM model system, we first present distributions of chemical species obtained for the baseline conditions (case A). Figure 2 shows the zonally and monthly mean distributions of carbon monoxide $(\mathrm{CO})$ and ozone $\left(\mathrm{O}_{3}\right)$ calculated for January (left) and July (right). In the case of CO, the zonally averaged mixing ratios are always higher in the Northern Hemisphere with a maximum in the boundary layer located between $30^{\circ}$ and $60^{\circ} \mathrm{N}$. The $\mathrm{CO}$ abundances are highest in winter with surface values of typically $180 \mathrm{ppbv}$ at $50^{\circ} \mathrm{N}$, to be compared to the $120 \mathrm{ppbv}$ calculated at the same location in summer. In the free troposphere, Northern Hemisphere winter values are decreasing from about $140 \mathrm{ppbv}$ at the top of the planetary boundary layer (PBL) to $75 \mathrm{ppbv}$ at $10-\mathrm{km}$ altitude. During summer, as vertical mixing is intense, the $\mathrm{CO}$ mixing ratio is more spatially uniform, with values ranging from $90 \mathrm{ppbv}$ at the top of the PBL to $60 \mathrm{ppbv}$ at $10 \mathrm{~km}$. Southern Hemisphere free tropospheric values $\left(50^{\circ} \mathrm{S}\right)$ are close to $50 \mathrm{ppbv}$ in both seasons.

Ozone is characterized by values decreasing gradually from the stratosphere to the surface. In the free troposphere, during all seasons, minimum mixing ratio values are found in the Tropics where vertical transport of ozone-poor air from the surface affects all levels up to $14 \mathrm{~km}$. Maximum values are derived by the model in the subtropics, where intrusions of stratospheric ozonerich air and downward motions tend to enhance the tropospheric ozone concentrations. This maximum is highest in the Northern Hemisphere where additional photochemical production associated with the relatively high levels of ozone precursors is taking place. In January, the zonally averaged extratropical ozone mixing ratio in the $1-5-\mathrm{km}$ layer ranges from 30 to $50 \mathrm{ppbv}$ in the Northern Hemisphere and from 10-30 ppbv in the Southern Hemisphere. In July, the corresponding values are 40-60 and 25-30 ppbv in the Northern and Southern Hemispheres, respectively.

Especially for short-lived species such as NOx, zonally averaged values do not provide a useful picture of the spatial distribution of tropospheric species. Large geographical differences primarily associated with the distribution of emissions exist and are illustrated in Fig. 3. This graph displays the surface distribution of monthly mean $\mathrm{NOx}, \mathrm{CO}$, and ozone mixing ratios for the month of July. In the case of NOx, the mixing ratio, which is lower than 50 pptv in most oceanic regions, reaches more than 10 ppbv in geographic areas where the use of fossil fuels is high and biomass activity is intense. Hot spots of NOx concentrations are found in the eastern United States, in northern Europe, and in East Asia. High values are also predicted in central Africa. The level of NOx decreases rapidly away from the continental zones even though a substantial enhancement is found along ship tracks. In the free tro- 

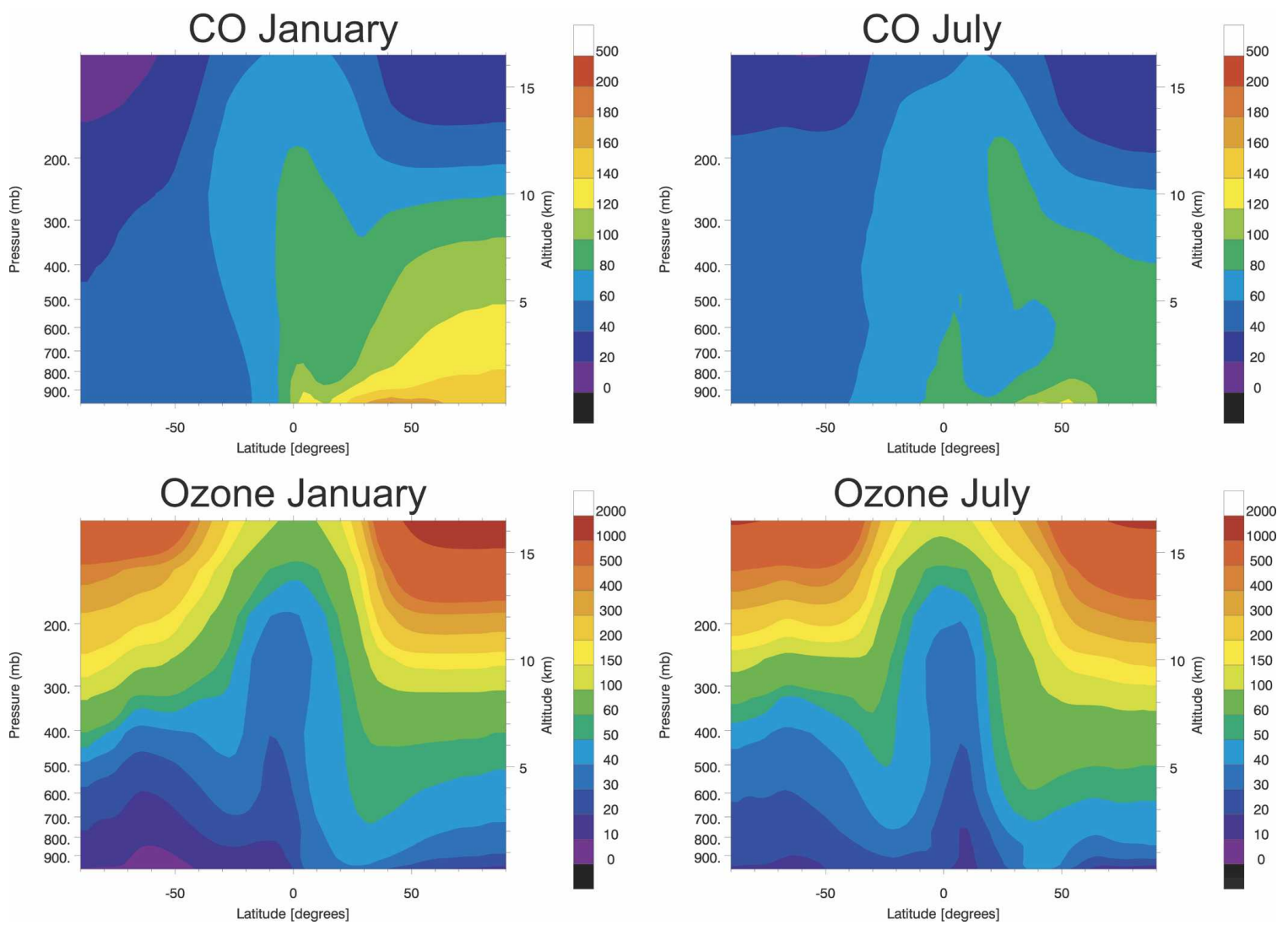

FIG. 2. Zonally averaged and monthly mean distributions of present-day (year 2000) carbon monoxide and ozone mixing ratios (ppbv) calculated for (left) January and (right) July, respectively (case A).

posphere (i.e., $5 \mathrm{~km}$; not shown), NOx mixing ratios larger than $100 \mathrm{pptv}$ are found over industrial areas of the United States and in India and China, where convective transport and lightning-related production of NOx are intense during certain periods of the year. Outside these areas, midtropospheric NOx mixing ratios are typically $20-40$ pptv and are determined by the interplay between long-range transported NOx from convective regions (uplift of boundary layer NOx and in situ lightning production), photochemical equilibrium between NOx and $\mathrm{HNO}_{3}$, and the formation and destruction rates of PAN.

In the case of $\mathrm{CO}$, whose lifetime is considerably longer than that of NOx, the distribution is spread farther away from the major source areas. The calculated surface mixing ratios are highest over the continents, although a plume of CO-rich air originating in North America is visible over the Atlantic Ocean. Surface mixing ratios reach typically $100-150$ ppbv in the summer Northern Hemisphere with peaks of several hundreds of ppbv in a few spots affected by intense industrial activity, transport, and biomass burning. In the
Northern Hemisphere during winter (not shown), the surface CO mixing ratio is of the order of $120-200 \mathrm{ppbv}$ outside the industrial hot spots.

Finally, in the case of ozone, the model provides a surface distribution characterized by summertime mixing ratios that are higher than $50 \mathrm{ppbv}$ in North America, Europe, and Asia, and less than 30 ppbv over the oceans (less than 15 ppbv over the tropical ocean). Elevated boundary layer ozone concentrations are calculated over the North Atlantic Ocean as a result of a westerly flow from North America and easterly transport of pollutants from Europe. In January, when the photochemical production of ozone is relatively weak north of $40^{\circ} \mathrm{N}$, the highest surface ozone mixing ratios are found in the subtropical band $\left(20^{\circ}-40^{\circ} \mathrm{N}\right)$ of the Northern Hemisphere, with the highest values being predicted over the ocean where ozone deposition is smallest. Ozone plumes originating from the regions of the Caribbean and eastern China are propagating over the North Atlantic and Pacific, respectively. The impact of biomass burning is also visible in Africa and to a lesser extent in South America and Indonesia. 

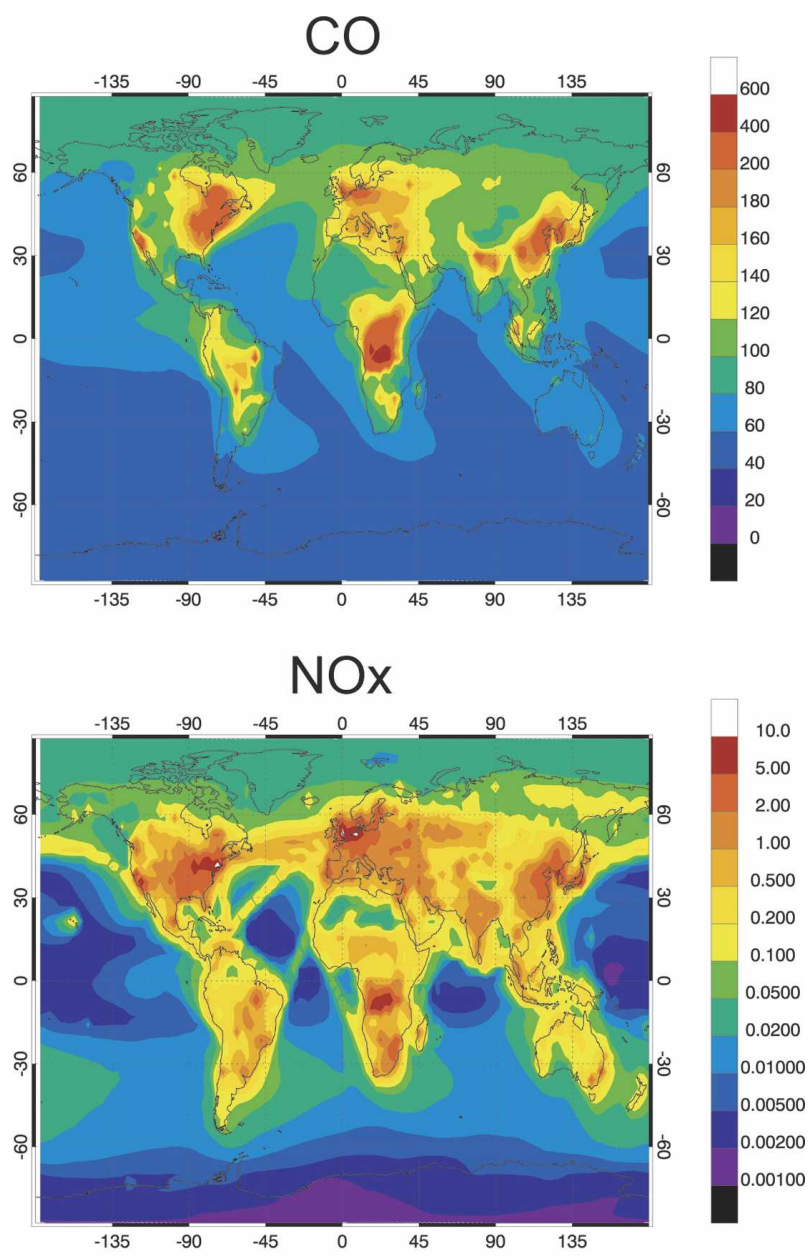

\section{Ozone}

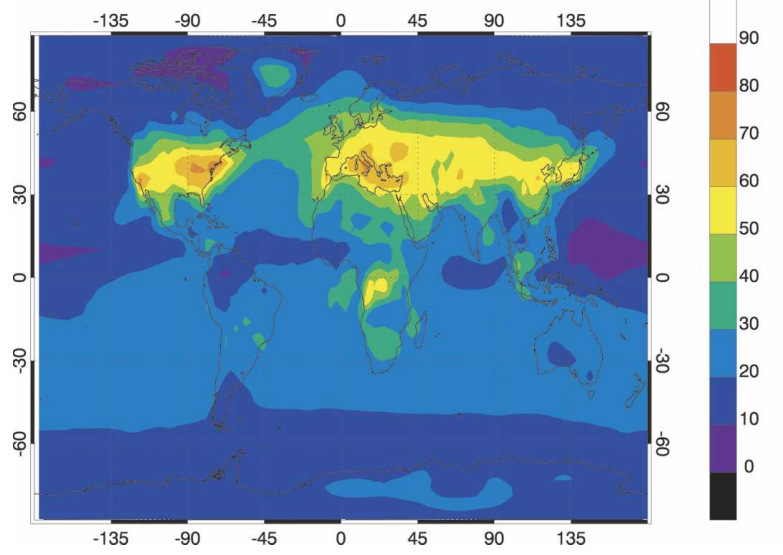

FIG. 3. Monthly mean present-day surface mixing ratio (ppbv) of carbon monoxide, nitrogen oxides, and ozone calculated for July (case A).

\section{b. Changes since the preindustrial era}

To provide a reference to which current and future changes in the chemical composition of the atmosphere can be compared, we first consider conditions represen- tative of the preindustrial era (year 1890). The assumptions made for this simulation are provided in section 3 (case P). As can be seen in Fig. 4a, the surface mixing ratio of ozone in July is generally of the order of 5-20 ppbv in all regions of the world, with values somewhat higher in the Southern (winter) than in the Northern (summer) Hemisphere. Values of 10-20 ppbv are calculated during July in Europe, the eastern United States, northern and southern Africa, and Australia, in general agreement with the concentrations measured at the end of the nineteenth century and reported by Pavelin et al. (1999). Surface mixing ratios slightly lower than $10 \mathrm{ppbv}$ are calculated in the region of the Sahara, in the northern part of South America and in Japan. The values exceeding $20 \mathrm{ppbv}$ over the North American and Asian continents reflect the influence of NOx emissions by the soils and the low deposition velocities in arid or semiarid continental regions. In the Northern Hemisphere, the calculated increase in surface ozone between years 1890 and 2000 is of the order of a factor 2 during July (Fig. 4b), except in industrialized and urbanized areas, where it reaches a factor of 4 or even 5 (more than $30 \mathrm{ppbv}$ ). In addition, the concentration of boundary layer ozone transported over the North Atlantic Ocean has increased by a factor of 3-4 (more than 20 ppbv). In January (Fig. 4c), the calculated Northern Hemispheric surface ozone concentration increases by $50 \%-100 \%$ (10-20 ppbv) over the oceans and is multiplied by a factor of $2-3$ over the continents, except over highly polluted areas, where it is reduced $(10 \%-50 \%)$ through titration by $\mathrm{NOx}$, whose concentrations are particularly high in these regions during wintertime. In the Southern Hemisphere, the ozone mixing ratio increases by $30 \%-75 \%$ over the oceans between 1890 and 2000. Above the continents, the calculated increase over the same period is typically 5-10 ppbv or $50 \%-150 \%$ in July. The global annual mean ozone column abundance increases from 21 to 30 Dobson Units (DUs).

The calculated change in the oxidizing power of the atmosphere [as measured by the mean tropospheric loss of methane by the hydroxyl $(\mathrm{OH})$ radical] is rather limited between 1890 and 2000 in the present model simulation in spite of substantial changes in the emissions of ozone precursors and in the atmospheric abundance of methane. The globally averaged lifetime of methane, calculated below the surface pressure of 200 $\mathrm{hPa}$, and used here as a measure of the oxidizing power of the troposphere, is reduced from $7.7 \mathrm{yr}$ in 1890 to 7.5 $\mathrm{yr}$ in 2000. Note that, when performing the calculation up to the tropopause level (rather than the 200-hPa pressure level), Horowitz et al. (2003) report a methane lifetime of $9.4 \mathrm{yr}$ for present-day conditions. 
a)

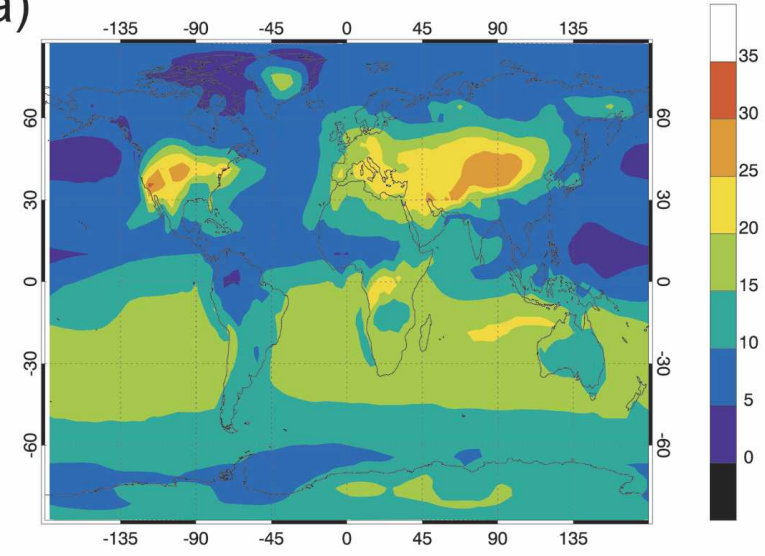

b)



c)

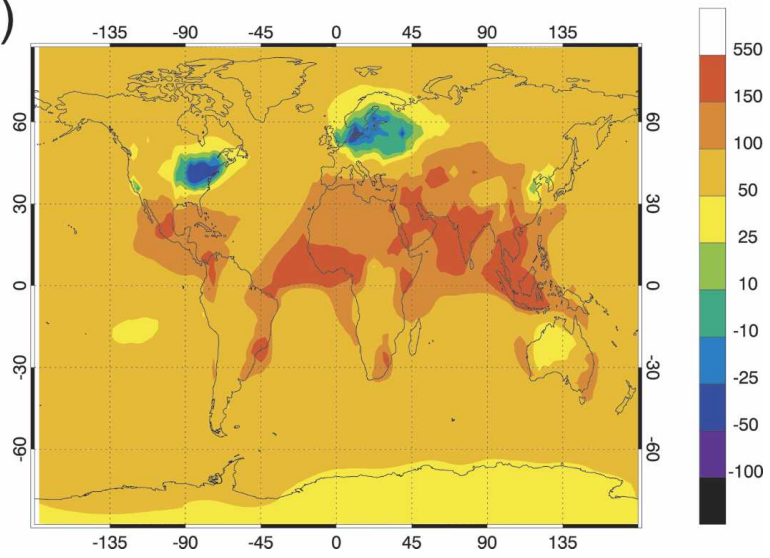

FIG. 4. Monthly mean ozone mixing ratio (a) calculated for preindustrial (1890) conditions (case P) in July (expressed in ppbv). Relative change (percent) between 1890 and 2000 in the surface ozone mixing ratio for (b) July and (c) January conditions (case A - case P).

\section{c. Future changes in tropospheric composition}

In the present section, we assess the changes to be expected in the chemical composition of the troposphere between the 2000 and 2100 periods, assuming that the emissions are changing according to scenario A2P, as described in section 3. The results presented here are not obtained from a transient integration over time, but are based on "snapshot" calculations: as stated above, the MOZART model is integrated over a period of $10 \mathrm{yr}$ with $10 \mathrm{yr}$ of dynamical evolution taken from the ECHAM5/OM-1 model and representative of periods close to years 2000 and 2100, respectively. Different conditions are considered.

\section{1) Emissions of 2100, climate of 2000 (CASE D)}

MOZART is integrated using chemical emissions representative of year 2100. The tropospheric mixing ratio of methane is fixed at the surface at $3.6 \mathrm{ppbv}$, that is, about twice the value observed in year 2000. At each grid point of the model, the emissions by commercial aircraft engines are assumed to be 4 times larger than in year 2000. An additional simulation (case C) in which the aircraft emissions remain unchanged from their present values is also considered. The difference between cases $\mathrm{D}$ and $\mathrm{C}$ provides an estimate of the effects of quadrupling the current aircraft emissions. In the present simulation, climatic and meteorological conditions are the same as for the year 2000 simulation. See section 3 for a description of the adopted emissions.

Figure 5a displays the relative change in the surface mixing ratio of carbon monoxide for July conditions. In remote areas far away from the spot sources, $\mathrm{CO}$ concentrations are enhanced by about $70 \%-90 \%$ between years 2000 and 2100, when the A2P scenario is adopted. In areas of high urban and industrial development (South Asia and South America), as well as in Africa, increases of more than $100 \%$ are predicted. Changes are considerably smaller in the regions affected primarily by North American and European emissions; they are typically $20 \%-50 \%$. In the free troposphere (not shown), changes are predicted to be of the order of $60 \%-70 \%$ in the Northern Hemisphere and $80 \%$ in the Southern Hemisphere.

In the case of NOx (Fig. 5b), the largest changes in the surface concentrations are located in the vicinity of the urban development zones (especially in the Tropics and Southern Hemisphere) with little dispersion far away from the sources. In the free troposphere (not shown), the perturbations are spread over larger distances, and average changes of typically $50 \%-80 \%$ occur in the tropical and subtropical regions.

Between years 2000 and 2100, the average change in the zonally averaged ozone concentration for scenario A2P is of the order of $75 \%$ near the equator, and larger than $50 \%$ everywhere in the Tropics at all altitudes 
a)

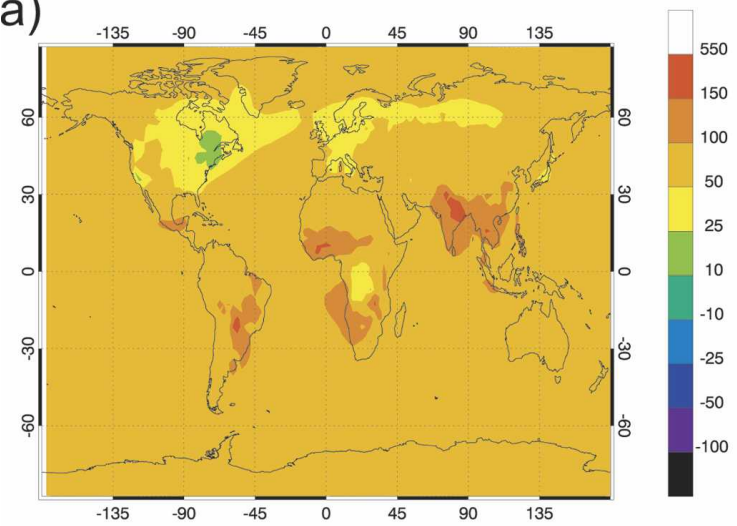

c)

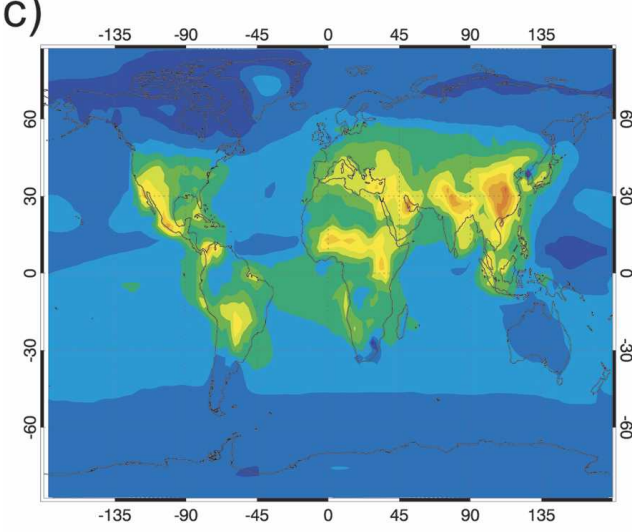

b)

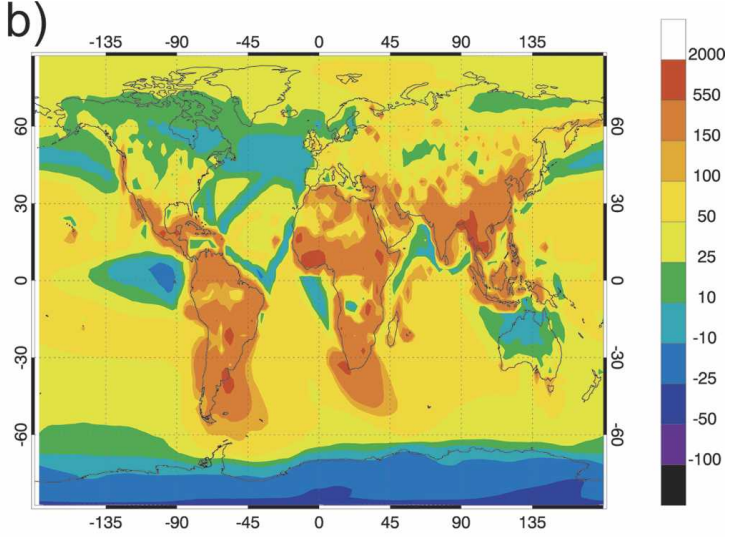

d)

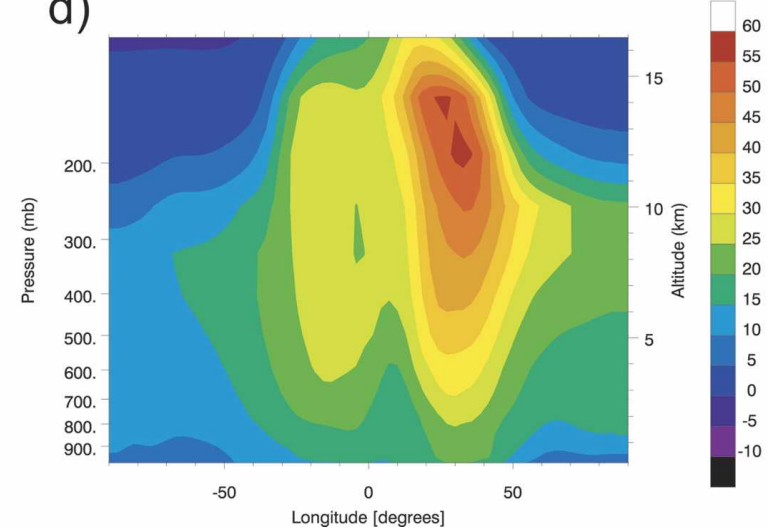

FIG. 5. Relative change (percent) in the monthly mean (July) surface concentration of (a) carbon monoxide, (b) nitrogen oxides, and (c) ozone, as well as (d) in the zonal mean zone concentration, between years 2000 and 2100 under the A2P scenario and for unchanged climate conditions (case D - case A).

between the surface and the upper troposphere (all seasons). In July, changes the extratropics for the same period are estimated to be of the order of $35 \%-40 \%$ in the Northern Hemisphere and $40 \%-45 \%$ in the Southern Hemisphere. Expressed as mixing ratios, the calculated changes are of the order of 25-30 ppbv near the equator (middle and upper troposphere). They reach slightly more than $50 \mathrm{ppbv}$ at $20^{\circ}-40^{\circ} \mathrm{N}$ between 10 and $15 \mathrm{~km}$ in July, and slightly more than $35 \mathrm{ppbv}$ at $10^{\circ}-$ $30^{\circ} \mathrm{S}$ in January. These changes derived for fixed ozone levels in the stratosphere are consistent with the variations projected for the same scenario by most of the 11 chemical transport models, and reported by Gauss et al. (2003).

At the surface (Fig. 5c), the largest ozone increase in July (more than a doubling of current values) is predicted for South Asia (India, southern China, and the Indo-Chinese peninsula). In Europe and North America, surface ozone increases by $35 \%-50 \%$ and $10 \%-25 \%$, respectively. Monthly mean mixing ratios (July) at the surface reach more than $80 \mathrm{ppbv}$ in large parts of California, China, northern India, and the Middle East (not shown). They become larger than 50 ppbv over the entire North American, European, and Asian continents south of $55^{\circ} \mathrm{N}$. On an annual basis, the changes in the surface mixing ratios are larger than 10 ppbv over the continents in the Tropics and reach more than $25 \mathrm{ppbv}$ in western Mexico and the center of Brazil and of Africa as well as in the region of the Persian Gulf, India, and Southeast Asia. Changes of more than 35 ppbv are projected in parts of southern Asia. Over the oceans, the ozone increase is less than 10 pptv except in a zonal band around $30^{\circ} \mathrm{N}$, where it slightly exceeds this value. The calculated changes in the annually averaged ozone changes at the surface, including the geographical patterns, are in good agreement with the values derived by Prather et al. (2003) from the predictions of 10 models following the same scenario.

Finally, the calculations show that, for the A2P scenario, the oxidizing power of the atmosphere decreases slightly during the next century (assuming no climate change) with the calculated methane lifetime increasing from $7.5 \mathrm{yr}$ in 2000 to $7.9 \mathrm{yr}$ in 2100 . 
2) EMissions of 2100, CLIMATE of 2100 (CASE E)

The assumptions made for case $\mathrm{E}$ are similar to the conditions described in the previous section (case D), except that the changes in climate predicted by the ECHAM5/OM-1 model between years 2000 and 2100 are also taken into account. The change in climate manifests itself through changes in tropospheric temperature, water vapor abundance, circulation, cloudiness, convective activity, lightning frequency, and precipitation rates. To characterize the 2100 climate generated by the ECAHM5/OM-1 model, Table 3 presents the globally averaged temperature and water vapor mass mixing ratios at selected atmospheric levels, and the changes predicted between 2000 and 2100 for January and July, respectively. These values should be compared with the similar calculations performed with the Second Hadley Centre Atmospheric Model (HadAM2b; Johnson et al. 1999). The changes in the zonal mean temperature and water vapor (July) are shown in Figs. 6a,b. Precipitation is also modified in 2100 when compared to present-day (Fig. 6c). In July, for example, convective rainfall increases in the monsoon region of South Asia and in the western tropical Pacific, while precipitation decrease in the tropical Atlantic and in the eastern Pacific. Such changes affect the removal rate of soluble species such as nitric acid and hydrogen peroxide.

The sensitivity of lightning frequency and intensity to climate change is not well established. Price and Rind (1994) derive from their climate model a 5\%-6\% increase in global lightning activity per kelvin global warming, and hence an equivalent number for the related NOx production. Grenfell et al. (2003) find that the NOx production increases from 4.9 to $6.9 \mathrm{TgN} \mathrm{yr}^{-1}$ for a warming of $3.25 \mathrm{~K}$ (2100-2000), which cor-

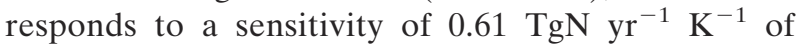

TABLE 3. Globally averaged temperature $(\mathrm{K})$ and water vapor mass mixing ratio (10-3 $\mathrm{kg} \mathrm{kg}^{-1}$ ) corresponding to year 2000 , and the changes (in the same units) predicted for year 2100.

\begin{tabular}{ccccc}
\hline $\begin{array}{c}\text { Model } \\
\text { level } \\
(\mathrm{hPa})\end{array}$ & Temp & $\begin{array}{c}\text { Temp } \\
\text { change }\end{array}$ & $\begin{array}{c}\text { Water mass } \\
\text { ratio }\left(10^{-3}\right)\end{array}$ & $\begin{array}{c}\text { Change in } \\
\text { mass ratio } \\
\left(10^{-3}\right)\end{array}$ \\
\hline \multicolumn{5}{c}{ January } \\
190 & 213.9 & +2.8 & 0.02 & +0.01 \\
320 & 235.0 & +3.2 & 0.24 & +0.10 \\
590 & 263.8 & +2.4 & 1.94 & +0.40 \\
850 & 278.2 & +2.2 & 5.78 & +0.81 \\
& \multicolumn{5}{c}{ July } & & \\
190 & 214.6 & +3.5 & 0.03 & +0.02 \\
320 & 237.5 & +4.0 & 0.31 & +016 \\
590 & 266.5 & +2.8 & 2.41 & +0.54 \\
850 & 281.6 & +2.3 & 6.73 & +1.11 \\
\hline
\end{tabular}
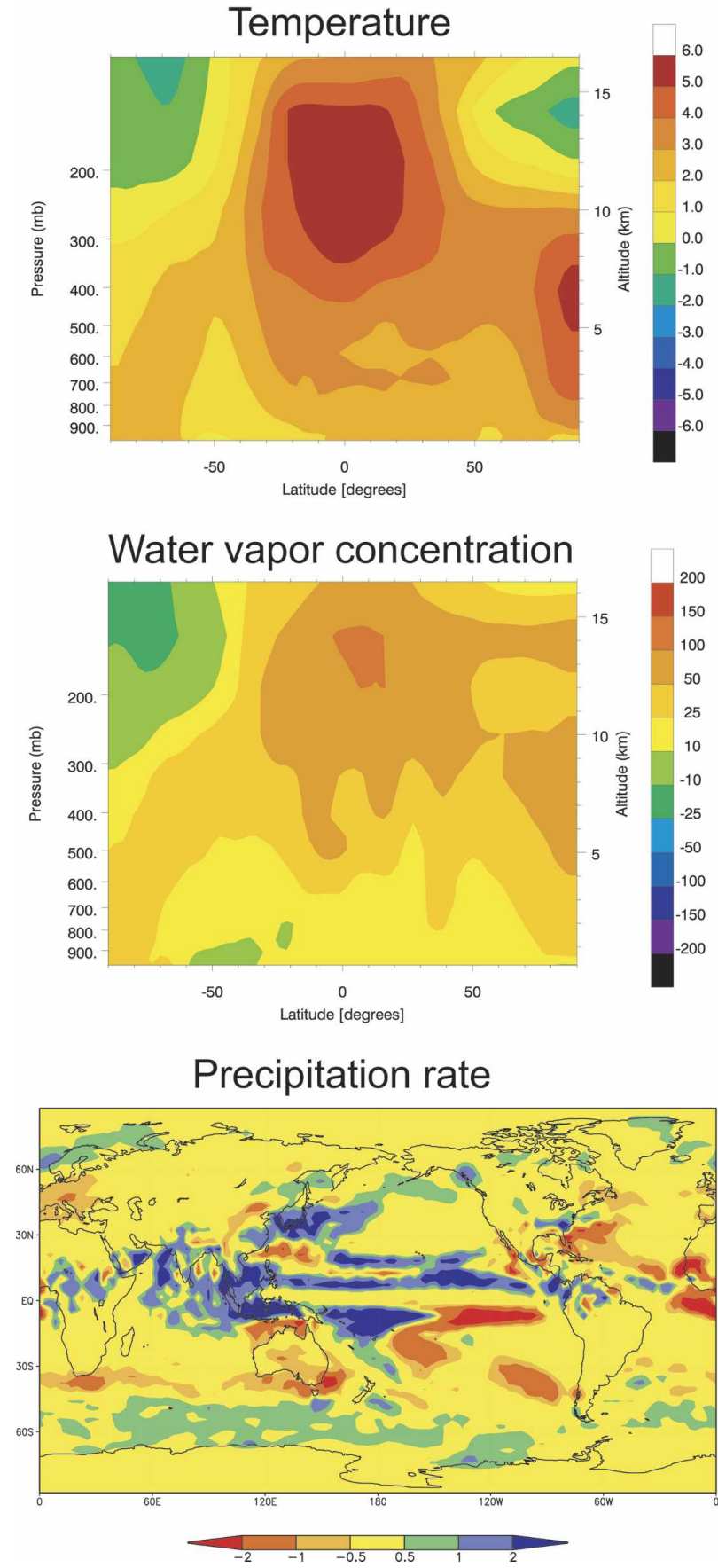

FIG. 6. Changes in the zonally averaged monthly mean (July) (top) temperature $(\mathrm{K})$ and (middle) water vapor concentration (percent) resulting from climate changes (doubling of $\mathrm{CO}_{2}$ level) as calculated the ECHAM5/OM-1 coupled atmosphere-ocean model (case B - case A). (bottom) Change in the precipitation rate $\left(\mathrm{mm} \mathrm{day}^{-1}\right)$ for the corresponding cases.

$12 \% \mathrm{~K}^{-1}$. Grewe et al. (2002) report a rather small signal [5.4 to $5.6 \mathrm{TgN} \mathrm{yr}^{-1}$ from 1992 to 2015 with climate change according to the Intergovernmental Panel on Climate Change (IPCC) IS92a scenario]. Stevenson 
et

al. (2005) report no significant trend in the global magnitude of lightning NOx emissions in their coupled climate chemistry model experiments performed for the 1990-2030 period under the IS92a scenario. They observe, however, some shifts in the distribution of the lightning, including a significant reduction in the Tropics below $10 \mathrm{~km}$ and an increase at higher levels reflecting reduced, but deeper convection. Figure 7 shows the change between 2000 and 2100 in the monthly mean globally integrated NOx production from lightning derived in MOZART as a result of changing climate. An increase of approximately $20 \%$ is predicted globally, even though changes can be much larger locally. This corresponds to a sensitivity of approximately $9 \% \mathrm{~K}^{-1}$. It should be noted that the lightning parameterization adopted in MOZART is based on cloud-top heights (Price and Rind 1993), which is used as a surrogate for convective activity. Thus, the results obtained here should be regarded as a simple sensitivity study rather than a quantitative prediction.

Rather than displaying the overall calculated changes (case E - case A) in the concentrations of chemical species (which resemble those shown in Fig. 5, but with slightly different values), we will show the changes produced only by the changes in climate for the period 2000-2100 (case E - case D). Figure 8 shows the climate-driven change in the zonal mean concentration of $\mathrm{CO}, \mathrm{NOx}$, and $\mathrm{O}_{3}$ (July average). The largest drivers associated with climate change are the changes in the background water vapor abundance and in the lightning-related NOx sources. As indicated by Fig. 6b, the

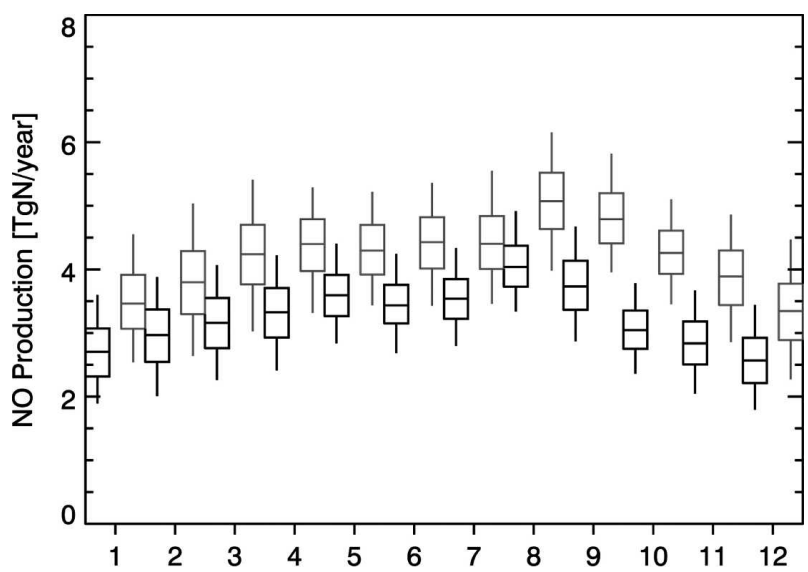

FIG. 7. Global production of $\mathrm{NOx}\left(\mathrm{TgN} \mathrm{yr}^{-1}\right)$ by lightning for different months of the year calculated for conditions representative of years $2000\left(\mathrm{CO}_{2}=370 \mathrm{ppmv}\right)$ and $2100\left(\mathrm{CO}_{2}=740\right.$ ppmv), and using the Price and Rind (1993) parameterization. The changes in meteorological conditions are those estimated by the ECHAM5/OM-1 climate model for a doubling of atmospheric $\mathrm{CO}_{2}$ concentrations.
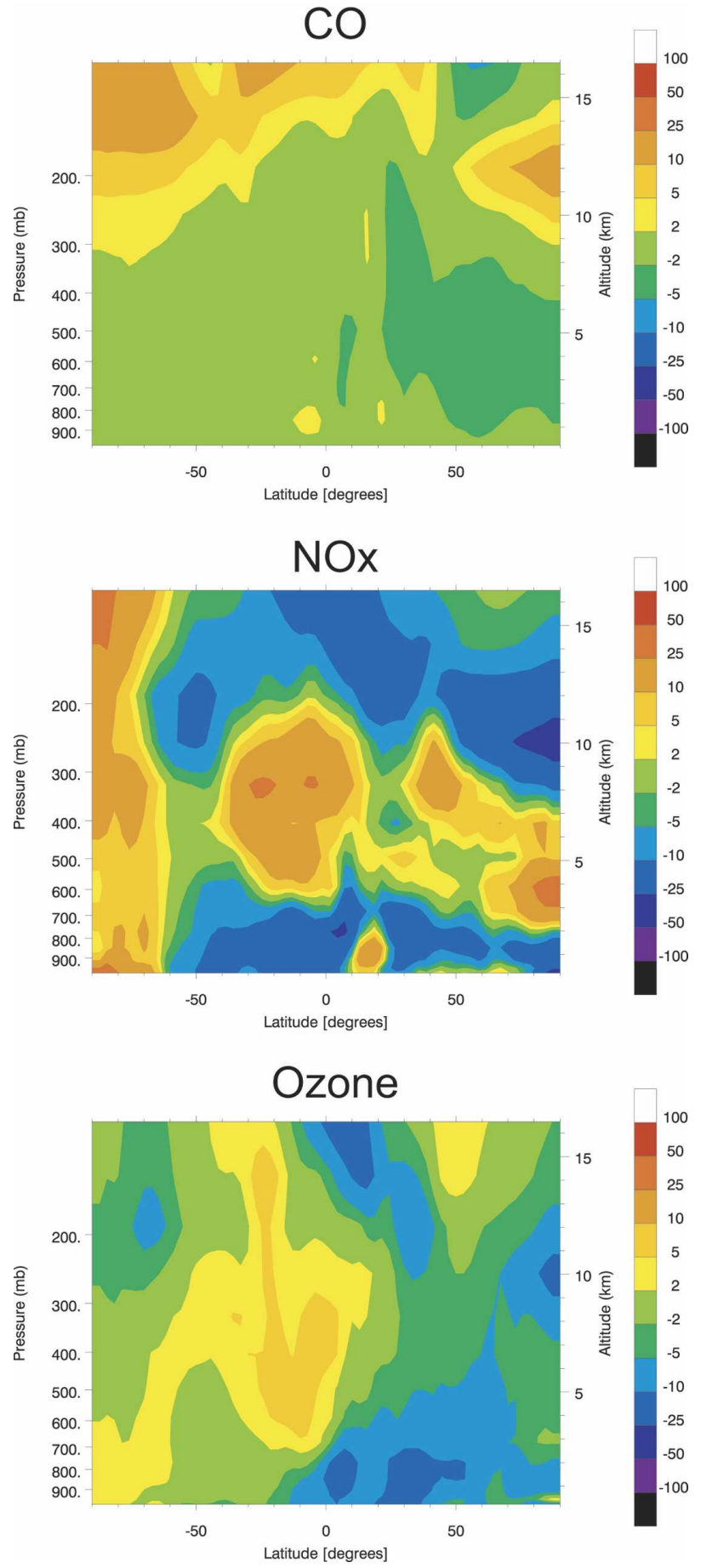

FIG. 8. Relative change (percent) in the monthly mean (July) zonally averaged concentration of (a) carbon monoxide, (b) nitrogen oxides, and (c) ozone due to changes in climate conditions for the years 2000 and 2100 (doubling in equivalent $\mathrm{CO}_{2}$ concentration) as estimated by the ECHAM5/OM-1 climate model (case E - case D) 
water vapor mixing ratio (zonal mean for July) increases by as much as $100 \%$ in the tropical upper troposphere. In the extratropical regions between 5 and 15 $\mathrm{km}$, it increases by $30 \%-70 \%$ in the summer (northern) hemisphere and by $20 \%-40 \%$ in the winter (southern) hemisphere. In the case of NOx, substantial concentration increases $(10 \%-30 \%)$ are predicted in the upper levels of the Tropics and summertime extratropics in response to enhanced lightning activity and, in addition, to faster decomposition of PAN. The $\mathrm{OH}$ concentrations are generally enhanced in response to increased water vapor and NOx abundances. The climateinduced change in the concentration of $\mathrm{CO}$ is limited because both the atmospheric production (hydrocarbon oxidation) and the destruction of this compound are proportional to the $\mathrm{OH}$ level. In response to climate change, the zonal mean ozone concentration decreases by approximately $5 \%-10 \%$ in the extratropical summer hemisphere, primarily because of the enhanced levels of water vapor. In the Tropics, it increases by $5 \%-10 \%$ because of elevated NOx production by lightning. The small ozone increase of $2 \%-3 \%$ in the Southern Hemisphere (winter; low photochemical activity) is attributed to the transport of tropical air masses with enhanced ozone concentrations.

Figure 9a shows that the changes in NOx at $500 \mathrm{hPa}$ resulting from climate change only are quite irregular in space, because they are associated with changes in the geographic location of convective regions as predicted by the ECHAM-OM climate model. The changes in the midtropospheric ozone concentration (Fig. 9b) follow those of NOx, with several spots in the vicinity of enhanced lightning areas. Away from these spots, the ozone concentration generally decreases.

The lifetime of methane, which is used as a surrogate for the oxidizing power of the atmosphere, is also affected by climate change. Our calculations suggest that the introduction of the climate change effects in the model simulation reduce the lifetime of methane by approximately $0.8 \mathrm{yr}$. Thus, this climate feedback effect is expected to reduce the atmospheric concentration of $\mathrm{CH}_{4}$, and hence reduce climate forcing produced by this chemical compound.

An interesting feature noted in the NOx and ozone changes during July, and associated with the climaterelated perturbations, is the large increase predicted for the abundance of these compounds over the Indian Ocean in the vicinity of the equator. This particular feature is attributed to changes in the July circulation that are predicted in this region by the ECHAM-OM model. As shown in Fig. 10, the shape of the dynamical barrier (9-yr average) for water vapor changes from a wavy structure in year 2000 to a more zonally uniform

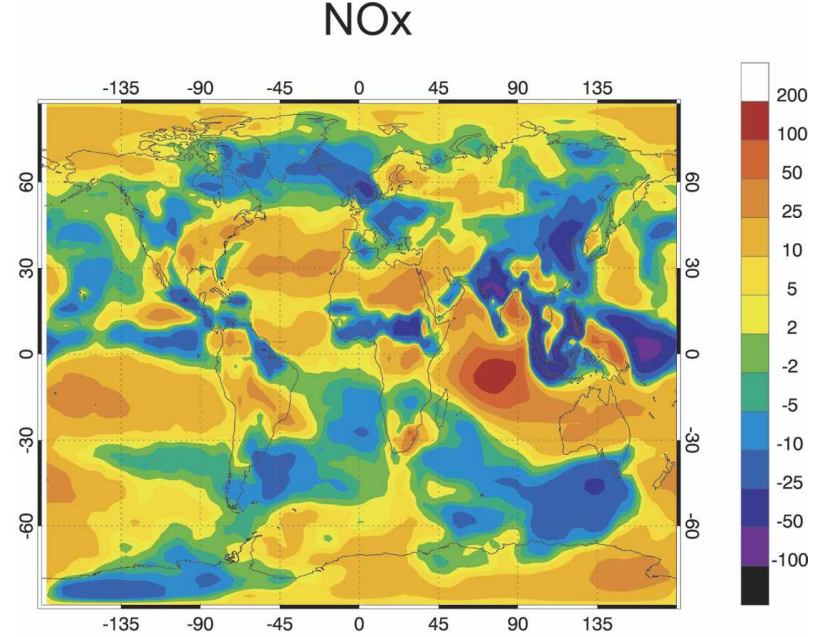

\section{Ozone}

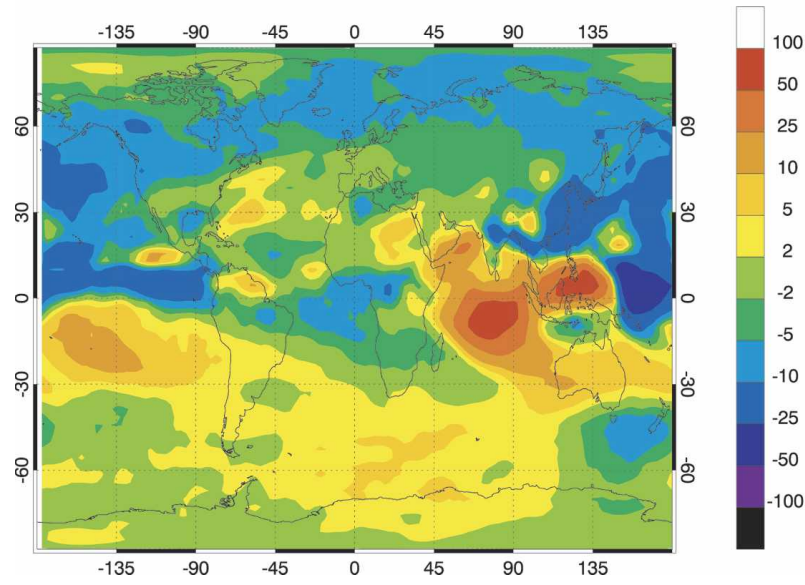

FIG. 9. Relative change (percent) in the monthly mean (July) concentration of (a) nitrogen oxides and (b) ozone at $500 \mathrm{hPa}$ due to changes in climate conditions for the years 2000 and 2100 (doubling in equivalent $\mathrm{CO}_{2}$ concentration) as estimated by the ECHAM5/OM-1 climate model (case E - case D).

shape in 2100. Changes in the concentration of ozone and other compounds in the vicinity of such a particular event can be very large. The dynamics of the tropopause region is also somewhat modified as a result of climate change. With the assumptions adopted here, the mean height of the tropical tropopause increases by approximately $600 \mathrm{~m}$ between years 2000 and 2100 . The meridional circulation is slightly enhanced, leading, for example, to a small increase (about 1\%) in the methane mixing ratio in the tropical lower stratosphere, and an equivalent decrease in the extratropical upper troposphere.

Finally, it should be stressed that the differences in the chemical fields resulting from climate change shown here for chemical emissions representative of year 2100 


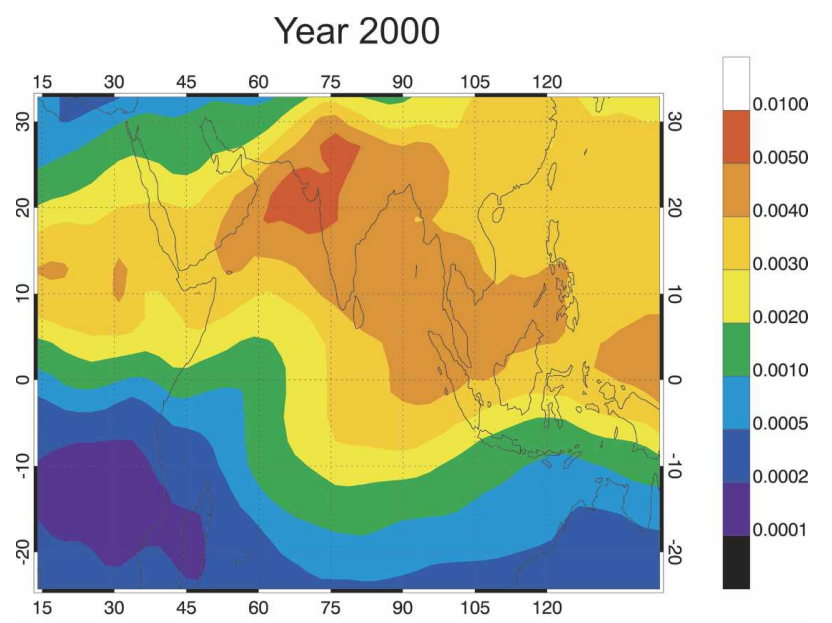

Year 2100



FIG. 10. Water vapor volume mixing ratio $(500 \mathrm{hPa})$ over the Indian Ocean in 2000 (case A) and 2100 (case B), highlighting the changes in the monsoon circulation as estimated by the ECHAM5/OM-1 climate model.

(case E - case D) are not significantly different from the similar differences calculated for chemical emissions at their year 2000 level (case B - case A). Both cases highlight the indirect effects of a $\mathrm{CO}_{2}$ doubling on the concentrations of ozone and other chemical compounds through changes in atmospheric temperature, water vapor concentrations, and dynamics.

\section{3) IMPACT OF METHANE TRENDS}

Crutzen (1988), Thompson et al. (1992), and more recently Fiore et al. (2002) have highlighted the importance of methane to background tropospheric ozone. Since the recent trends observed in atmospheric methane are not well understood, and consequently future trends are highly uncertain, it is important to assess the impact of future methane scenarios on calculated ozone (Fiore et al. 2002). The results presented above (see, e.g., Fig. 5) assume a relatively large increase in the methane mixing ratio during the twenty-first century (from 1.7 ppmv in year 2000 to 3.6 ppmv in 2100). We also consider an additional scenario (case F), in which the methane level in 2100 remains the same as in 2000 (no methane trend). The emissions of other compounds follow the A2P scenario as above, and the "equivalent" $\mathrm{CO}_{2}$ level is assumed to double during the twenty-first century as in case E. Note a slight inconsistency in this assumption since the lack of methane trend should slightly reduce the growth in the equivalent $\mathrm{CO}_{2}$ forcing. However, as we are performing a sensitivity case to assess the photochemical role of methane, all other factors are maintained as in the previous case. Figures 11a,b compare the changes in the zonally averaged ozone concentrations when the methane trend is included (case E) and when it is ignored (case F). The difference in the zonal ozone average concentration in the Tropics is close to $20 \%$ between these two scenarios. The difference associated with the uncertainty in the future
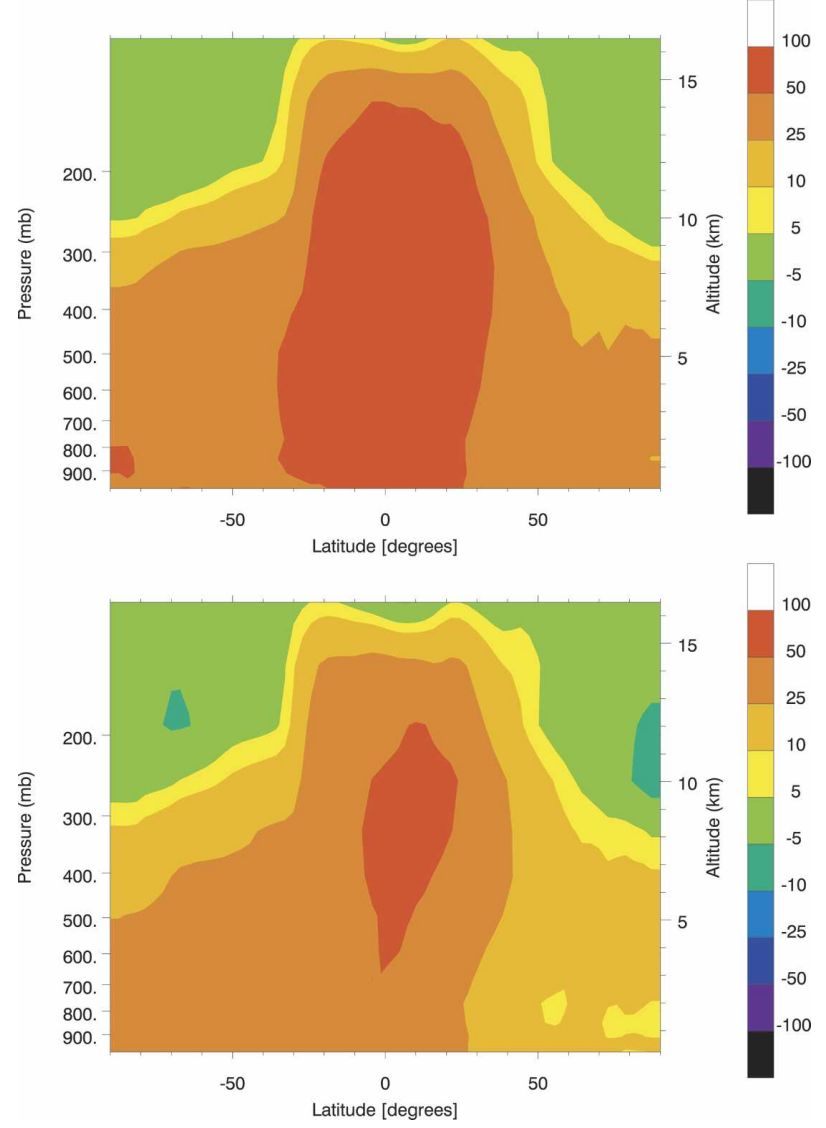

FIG. 11. Percent change in the July zonally averaged ozone concentration between years 2000 and 2100, when the adopted change in the methane level (top) is included in the calculation (case E - case A) and (bottom) is ignored (case F - case A). 

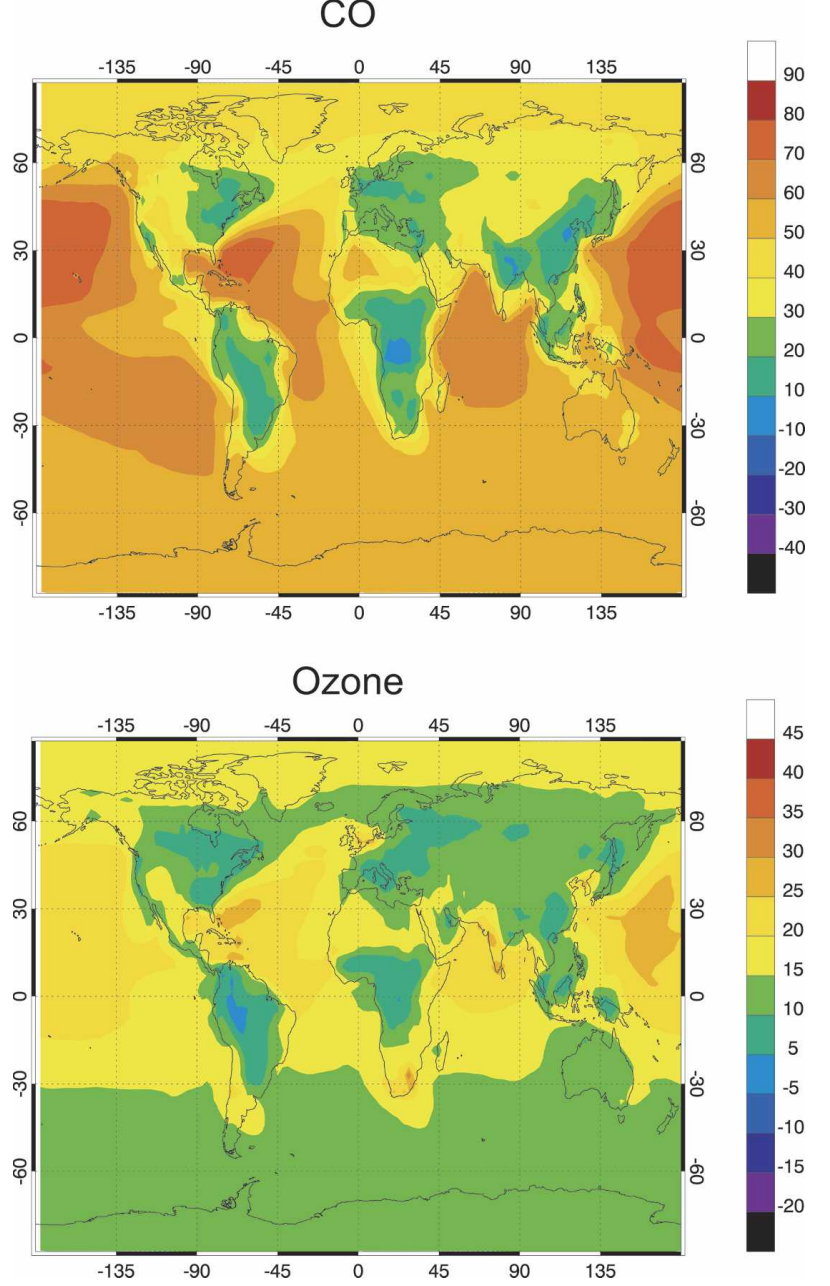

FIG. 12. Relative changes (percent) in the surface concentrations of (a) carbon monoxide and (b) ozone resulting from the increase in the methane level from its 2000 value ( $1.7 \mathrm{ppmv})$ to the assumed 2100 value (3.6 ppmv). July conditions (case E - case F).

methane trend is therefore larger than the calculated impact on ozone of the adopted climate change. Figures 12a,b show how the imposed trend in methane (case $\mathrm{E}$ - case $\mathrm{F}$ ) affects the $\mathrm{CO}$ and $\mathrm{O}_{3}$ surface concentrations. As anticipated, for both compounds, the effects of methane are most pronounced away from the continent, where nonmethane hydrocarbons play a minor role in the budgets of carbon monoxide and ozone, and hence mask the effect of methane. The increase in the methane level from 1.7 to 3.6 ppmv leads to an increase in the $\mathrm{CO}$ concentration of more than $60 \%$ over the tropical ocean, but of less than $30 \%$ over the most polluted continental areas. The corresponding increase in surface ozone is typically $10 \%-20 \%$ over the tropical ocean, but of less than $10 \%$ over the polluted areas of the continents.

Under the scenario in which the atmospheric abun- dance of methane remains at its present level, the oxidizing power of the atmosphere is substantially higher in 2100 than in 2000 . The $\mathrm{CH}_{4}$ lifetime calculated by the model is reduced from $7.1 \mathrm{yr}$ in 2000 to $5.5 \mathrm{yr}$ in 2100 , if the methane level is maintained at its year 2000 value. Thus, the future evolution of the atmospheric level of methane, a factor that is very uncertain, will not only affect climate forcing but also the oxidizing power of the atmosphere.

\section{Impacts of climate-driven changes in biogenic emissions}

Climate change, and specifically the warming of the earth's surface and the changes in the precipitation regimes, are expected to affect natural emissions, including the release of isoprene by vegetation and of nitric oxide by soils. Climate change could also lead to disturbances in the earth's ecosystems with additional impacts on the biogenic emissions. In turn, changes in these emissions should affect the tropospheric levels of ozone (Shallcross and Monks 2000; Sanderson et al. 2003; Lathière et al. 2005) and hence radiative forcing. An accurate quantification of these potential feedbacks would require the use of dynamic vegetation models coupled to climate models and accounting for the effect of changing emissions and changing deposition on vegetation. Because of the large uncertainties associated with current vegetation models as well as with the relations between emissions factors and environmental conditions, we restrict ourselves to a simple sensitivity test, in which we assess the potential impact on the tropospheric composition of a spatially uniform doubling of the biogenic isoprene and soil nitric oxide emissions. C. Wiedinmyer et al. (2005, personal communication) calculated that, in a climate characterized by a doubling in $\mathrm{CO}_{2}$, the total emission of isoprene would increase from its present value of $500 \mathrm{TgC}^{-1}$ to ap-

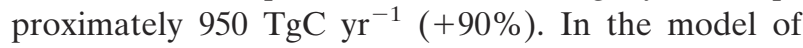
Lathière et al. (2005), the present-day isoprene emissions of $402 \mathrm{TgC} \mathrm{yr}^{-1}$ are increased to $638 \mathrm{TgC} \mathrm{yr}^{-1}$ $(+59 \%)$ in year 2100 in response to the combined effects of foliar expansion, climate change and ecosystem redistribution. Between present day and year 2100, the total biogenic emissions of organic compounds (isoprene, monoterpenes, methanol, acetone, acethaldehyde, formaldehyde, formic acid, and acetic acid) increase from 725 to $1251 \mathrm{TgC} \mathrm{yr}^{-1}$ (+72\%).

The sensitivity of microbial activity in soils to temperature also points toward a substantial increase in the NO emissions (see Yienger and Levy 1995). In the case discussed here (case G), the anthropogenic emissions of chemical species are representative of year 2100, and 
climate conditions are those calculated under a doubled $\mathrm{CO}_{2}$ level. Figure 13a shows the corresponding change in the isoprene mixing ratio near the surface, when the isoprene emissions specified according to Guenther et al. (1995) are uniformly multiplied by 2. Enhancements of more than 1-2 ppbv are found in the isoprene mixing ratios in the forested areas of Canada, Alaska, Siberia, Southeast Asia, and Australia. In the areas of tropical forests, the changes reach more than 4 ppbv and even more than $10 \mathrm{ppbv}$ in the western part of the Amazon.

The relative changes in the NOx concentrations are shown in Fig. 13b. The percentage changes are very small in regions where the NOx concentrations are high, that is, in areas strongly influenced by fossil fuel and biomass burning emissions. Increases of the surface NOx concentrations of $40 \%-80 \%$ are predicted in Alaska, northern Canada, and Siberia, as well as in the central plains of the United States and in central Australia. In relative terms, significant increases are also found over the ocean, especially in the Southern Hemisphere, where the background NOx concentrations are very low, and where nitrogen oxides can be transported from the continent, particularly during winter. The resulting change in surface ozone is shown in Fig. 13c for July. As expected, the largest percentage increases in the ozone concentration are found where elevated values of NOx are predicted. Climate-generated doubling in the isoprene and soil NOx emissions should lead to an increase in the surface ozone concentration by $5 \%-$ $10 \%$ in most areas during July, and even to up to $25 \%$ in specific areas (i.e., equatorial Pacific, central United States, Siberia, and sub-Sahara). A decrease in the surface ozone density by a few percent is predicted in the Amazon, due to the direct reaction of this biogenic hydrocarbon with ozone.

Finally, we assess the potential impact of climateinduced changes in the emissions associated with biomass burning. Here again, the future magnitude of these emissions is unknown. An intensification of wildfires is often associated with heat waves in the extratropics. However, more frequent fires could also lead to the destruction of the forest with a progressive reduction in fire frequency and intensity. Again, in order to quantify the sensitivity of potential changes in wildfire emissions, we consider a scenario (case $\mathrm{H}$ ) in which biomass burning emissions in 2100 are assumed to be twice the emissions of the year 2000, while the other emissions and the change in climate are specified as in case E. The level of methane in 2100 is assumed to be 3.6 ppmv. Figure 14 shows the impact of the biomass burning doubling on surface ozone during July. The
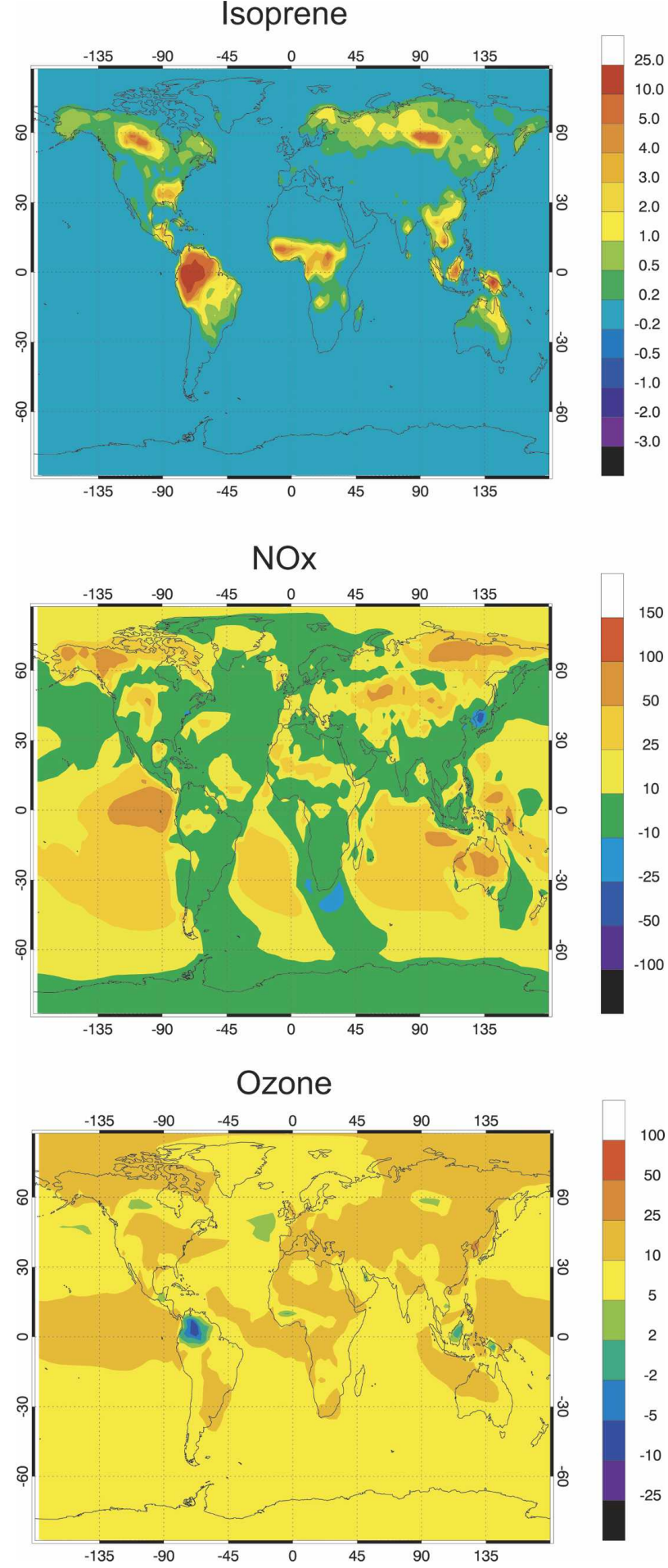

FIG. 13. Impact of a uniform doubling in the emissions of isoprene (vegetation) and nitric oxide (soils) for July conditions: (a) absolute change (ppbv) in the surface concentration of isoprene; (b) relative change (percent) in the surface concentration of $\mathrm{NOx}$; and (c) relative change (percent) in the surface concentration of ozone (case $\mathrm{G}$ - case E). 


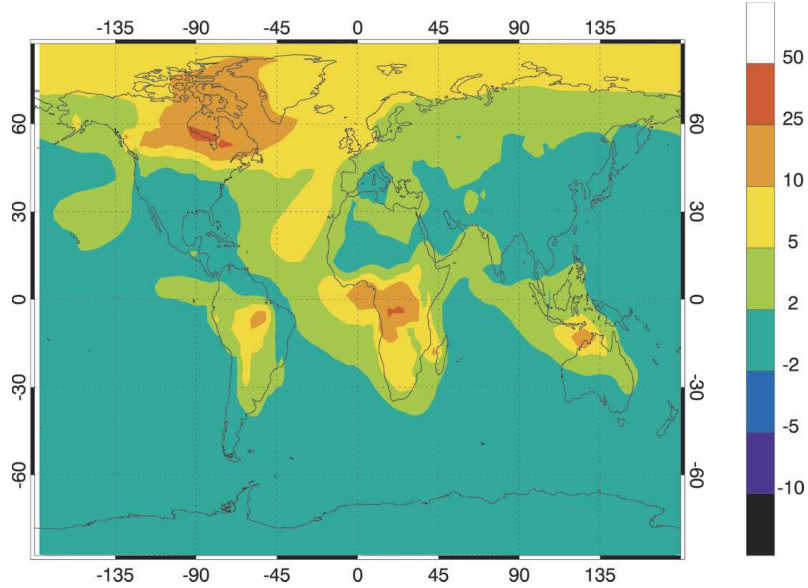

FIG. 14. Impact of a geographically uniform doubling in biomass burning emissions on the surface concentration of ozone (July average) calculated for year 2100 conditions (A2P emission scenario; $2 \times \mathrm{CO}_{2}$ climate) (case $\mathrm{H}-$ case $\mathrm{E}$ ).

changes are most pronounced in the Tropics $(10 \%-$ $15 \%)$ and in the summer boreal regions, specifically northern Canada, where large fires are assumed to occur. As climate-driven changes in wildfire frequency are expected to be more pronounced at high latitudes than in the Tropics (Stocks et al. 1998; Flannigan et al. 2000; Amiro et al. 2001), it is likely that this climaterelated effect will be most pronounced in the polar regions of the Northern Hemisphere.

\section{Conclusions}

Model calculations performed with the MOZART-2 model driven by the dynamics provided by the coupled ECHAM5/MPI-OM-1 atmosphere-ocean model show that substantial changes in the concentration of tropospheric ozone should have resulted from increasing emissions of chemical compounds in response to human activities. Since the preindustrial era, the surface concentration of ozone should have nearly doubled in many parts of the world, with increases reaching a factor of 3-4 in the industrialized regions of the Northern Hemisphere. Future changes in ozone will depend on several factors including population growth, economic development, and political decisions. Model predictions must therefore rely on scenarios. Most of these scenarios suggest that the levels of air pollutants and specifically of ozone will increase dramatically in South and Southeast Asia during the next decades. On the basis of the A2P scenario adopted in the present study, monthly averaged summertime surface ozone mixing ratios could reach $80 \mathrm{ppbv}$ in these regions by the year 2100. Changes are expected to be smaller in the indus- trialized regions of Europe and North America, where emissions are not expected to increase substantially.

The impact of future climate changes on the composition of the troposphere is not well quantified because it depends on the evolution of a multitude of climaterelated factors. Models show that the climate-driven increase in the tropospheric water vapor content, which should increase the concentrations of the $\mathrm{OH}$ and $\mathrm{HO}_{2}$ radicals, should somewhat damp the ozone increase expected from enhanced emissions of ozone precursors such as NOx. Our model calculates a reduction in ozone of typically $5 \%-10 \%$ in the extratropics during summertime in response to this climate-related effect. In the Tropics, however, ozone increases are amplified by $5 \%-8 \%$ (zonal mean) because of enhanced lightning activity predicted to occur in a warmer and wetter climate. Changes can, however, be locally substantially larger in regions where meteorological flows are strongly modified as a result of a future climate change. The impact of the climate changes on ozone calculated for the A2P scenario is generally smaller than the uncertainty in future ozone associated with the unknown changes in future methane concentrations.

Table 4 provides the changes between 2000 and 2100 in the globally averaged ozone mixing ratio on different model levels (January and July conditions) in response to prescribed changes in the anthropogenic emissions of ozone precursors and to calculated climate changes in the twenty-first century. The changes derived for a case in which the two types of perturbations are combined are also provided. When comparing these results with, for example, those of Johnson et al. (1999), it appears that the changes associated with the prescribed humaninduced emissions (A2P scenario) are typically a factor

TABLE 4. Globally averaged ozone mixing ratio (ppbv) on different model surfaces as calculated for year 2000 conditions, and changes (ppbv) in year 2100 resulting from emissions of chemical compounds, climate change (A2P scenario), and combined effects.

\begin{tabular}{|c|c|c|c|c|}
\hline Scenario & $950 \mathrm{hPa}$ & $770 \mathrm{hPa}$ & $500 \mathrm{hPa}$ & $320 \mathrm{hPa}$ \\
\hline \multicolumn{5}{|c|}{ January } \\
\hline Baseline case (2000) & 22.9 & 31.4 & 41.3 & 56.3 \\
\hline Effects of emissions & +12.4 & +16.9 & +22.3 & +23.9 \\
\hline $\begin{array}{l}\text { Effects of climate } \\
\text { change }\end{array}$ & -1.2 & -1.3 & +0.2 & +1.3 \\
\hline Combined effects & +10.5 & +14.3 & +20.5 & +23.2 \\
\hline \multicolumn{5}{|c|}{ July } \\
\hline Baseline case (2000) & 26.7 & 33.9 & 46.9 & 61.4 \\
\hline Effects of emissions & +14.8 & +18.7 & +24.8 & +28.1 \\
\hline $\begin{array}{l}\text { Effects of climate } \\
\text { change }\end{array}$ & -1.0 & -1.2 & +1.0 & +1.6 \\
\hline Combined effects & +12.6 & +16.0 & +24.7 & +28.6 \\
\hline
\end{tabular}


of 2-3 larger in our study. One should remember, however, that the adopted scenarios for these emissions are very different in the two model studies. The reduction in the ozone concentration resulting directly from climate change is about a factor of 2 larger in the study of Johnson et al. (1999) than in the present model simulations. This is probably explained by the fact that, in the present study, the relatively large positive effect resulting from changes in lightning NOx production compensates to a certain extent the negative effect associated with the calculated increase in the tropopsheric water vapor abundance.

Besides the direct climate-related perturbations simulated by the general circulation model, other indirect effects could have a substantial effect on future ozone. These include changes in the temperaturedependent emissions of biogenic compounds, changes in the frequency and intensity of wildfires, changes in surface deposition processes associated with ecosystem perturbations, and changes in sea-air exchanges and in dust mobilization. Our model simulations show that a doubling in the biogenic isoprene and soil NO emissions, and in the biomass burning emissions should have a significant effect on surface ozone. Changes in weather patterns, which have not been considered explicitly in the present study, could have a significant impact on future air quality, especially if the frequency of occurrence of summertime air stagnation events (a meteorological situation that favors the formation of ozone episodes in the extratropics) were to change in response to climate change (Mickley et al. 2004). Changes in the phase of the North Atlantic Oscillation could affect the long-range transport of pollutants from North America to Europe ( $\mathrm{Li}$ et al. 2002). Increased ventilation from the boundary layer due to enhanced convection could also modify the surface concentration of pollutants (Rind et al. 2001). A further study will attempt to address these questions.

Acknowledgments. The authors thank Hauke Schmidt for suggesting improvements on the manuscript and Ivar Isaksen for providing the model scenarios on chemical emissions used in the present study. They also acknowledge the support provided by the MOZART team at the National Center for Atmospheric Research (NCAR). M. Saunois was supported by the Phytem Program of the Ecole Normale Supérieure (Cachan) and by the Pierre and Marie Curie University (Paris 6). This work was financed in part by the German BMBF under the COMMIT Project. The model simulations were performed on the NEC SX-6 supercomputer installed at the German Climate Computer Center (DKRZ) in Hamburg, Germany.

\section{REFERENCES}

Amiro, B. D., B. J. Stocks, M. E. Alexander, M. D. Flannigan, and B. M. Wotton, 2001: Fire, climate change, carbon and fuel management in the Canadian boreal forest. Int. J. Wildland Fire, 10, 405-413.

Anfossi, D., S. Sandroni, and S. Viarengo, 1991: Tropospheric ozone in the ninetenth century: The Moncalieri series. $J$. Geophys. Res., 96, 17 349-17 352.

Berntsen, T., I. S. A. Isaksen, J. S. Fuglestvedt, G. Myhre, T. A. Larsen, F. Stordal, R. S. Freckleton, and K. P. Shine, 1997: Effects of anthropogenic emissions on tropospheric ozone and its radiative forcing. J. Geophys. Res., 102, 21 239-21 280.

$[,-$, G. Myhre, and F. Stordal, 2000: Time evolution of tropospheric ozone and its radiative forcing. J. Geophys. Res., 105, 8915-8930.

Brasseur, G. P., J. T. Kiehl, J.-F. Müller, T. Schneider, C. Granier, X. Tie, and D. Hauglustaine, 1998: Past and future changes in global tropospheric ozone: Impact on radiative forcing. Geophys. Res. Lett., 25, 3807-3810.

Crutzen, P. J., 1988: Tropopsheric ozone: An overview. Tropospheric Ozone, I. S. A. Isaksen, Ed., Reidel, Dordrecht, 3-32.

Dlugokencky, E. J., L. P. Steele, P. M. Lang, and K. A. Masarie, 1994: The growth rate and distribution of atmospheric methane. J. Geophys. Res., 99, 17 021-17 043.

European Commission, 2003: Ozone-climate interactions. Air Pollution Res. Rep. 81, Directorate General for Research, Environment and Sustainable Development Programme, EUR 20623, 143 pp.

Fiore, A. M., D. J. Jacob, B. D. Field, D. G. Streets, S. D. Fernandes, and C. Jang, 2002: Linking ozone pollution to climate change: The case for controlling methane. Geophys. Res. Lett., 29, 1919, doi:10.1029/2002GL015601.

Flannigan, M. D., B. J. Stocks, and B. M. Wotton, 2000: Climate change and forest fires. Sci. Total Environ., 262, 221-229.

Gauss, M., and Coauthors, 2003: Radiative forcing in the 21st century due to ozone changes in the troposphere and the lower stratosphere. J. Geophys. Res., 108, 4292, doi:10.1029/ 2002JD002624.

GLOBALVIEW-CH4, 2001: Cooperative Atmospheric Data Integration Project-Methane. NOAA/CMDL, Boulder, CO, CD-ROM. [Available online at ftp.cmdl.noaa.gov/ccg/ch4/ GLOBALVIEW.]

Grenfell, J. L., D. T. Shindell, and V. Grewe, 2003: Sensitivity studies of oxidative changes in the troposphere in 2100 using the GISS GCM. Atmos. Chem. Phys., 3, 1267-1283.

Grewe, V., M. Dameris, R. Hein, R. Sausen, and B. Steil, 2001: Future changes of the atmospheric composition and the impact of climate change. Tellus, 53B, 103-121.

,-- , C. Fichter, and R. Sausen, 2002: Impact of aircraft NOx emissions. Part 1: Interactively coupled climatechemistry simulations and sensitivities to climate-chemistry feedback, lightning and model resolution. Meteor. Z., 11, 177-186.

Guenther, A., and Coauthors, 1995: A global model of natural volatile organic compound emissions. J. Geophys. Res., 100, 8873-8892.

Hack, J. J., 1994: Parameterization of moist convection in the National Center for Atmospheric Research Community Climate Model (CCM). J. Geophys. Res., 99, 5541-5568.

Hauglustaine, D. A., and G. P. Brasseur, 2001: Evolution of tropospheric ozone under anthropogenic activities and associ- 
ated radiative forcing of climate. J. Geophys. Res., 106, 32 337-32 360.

Holtslag, A. A. M., and B. Boville, 1993: Local versus nonlocal boundary-layer diffusion in a global climate model. J. Climate, 6, 1825-1842.

Horowitz, L., and Coauthors, 2003: A global simulation of tropospheric ozone and related tracers: Description and evaluation of MOZART, version 2. J. Geophys. Res., 108, 4784, doi:10.1029/2002JD002853.

Houghton, J. T., Y. Ding, D. J. Griggs, M. Noguer, P. J. van der Linden, X. Dai, K. Maskell, and C. A. Johnson, Eds., 2001: Climate Change 2001: The Scientific Basis. Cambridge University Press, $881 \mathrm{pp}$.

Johnson, C. E., W. J. Collins, D. S. Stevenson, and R. G. Derwent, 1999: Relative roles of climate and emissions changes on future tropospheric oxidant concentrations. J. Geophys. Res., 104, 18 631-18 645.

Lamarque, J.-F., P. Hess, L. Emmons, L. Buja, W. Washington, and C. Granier, 2005: Tropospheric ozone evolution between 1890 and 1990. J. Geophys. Res., 110, D08304, doi:10.1029/ 2004JD005537.

Lathière, J., D. A. Hauglustaine, N. De Noblet-Ducoudre, G. Krinner, and G. Folberth, 2005: Past and future changes in biogenic volatile organic compound emissions simulated with a global dynamic vegetation model. Geophys. Res. Lett., 32, L20818, doi:10.1029/2005GL024164.

Latif, M., and Coauthors, 2004: Reconstructing, monitoring, and predicting multidecadal-scale changes in the North Atlantic thermohaline circulation with sea surface temperature. J. Climate, 17, 1605-1614.

Lelieveld, J., and R. van Dorland, 1995: Model simulations of ozone chemistry changes in the troposphere and consequent radiative forcing of climate during industrialization. Atmospheric Ozone As a Climate Gas, W. C. Wang and I. S. A. Isaksen, Eds., NATO ASI Series, Vol. 32, Springer-Verlag, 227-258.

Li, Q. B., and Coauthors, 2002: Transatlantic transport of pollution and its effects on surface ozone in Europe and North America. J. Geophys. Res., 107, 4166, doi:10.1029/ 2001JD001422.

Lin, S. J., and R. B. Rood, 1996: Multidimensional flux-form semiLagrangian transport schemes. Mon. Wea. Rev., 124, 20462070.

Marsland, S. J., H. Haak, J. H. Jungclaus, M. Latif, and F. Röske, 2003: The Max-Planck-Institute global ocean/sea ice model with orthogonal curvilinear coordinates. Ocean Modell., 5, 91-127.

Mickley, L. J., P. P. Murti, D. J. Jacob, J. A. Logan, D. Rind, and D. Koch, 1999: Radiative forcing from tropospheric ozone calculated with a unified chemistry-climate model. J. Geophys. Res., 104, 30 153-30 172.

— D. J. Jacob, B. D. Field, and D. Rind, 2004: Effects of future climate change on regional air pollution episodes in the United States. Geophys. Res. Lett., 31, L24103, doi:10.1029/ 2004GL021216.

Murazaki, K., and P. Hess, 2006: How does climate change contribute to surface ozone change over the United States? J. Geophys. Res., 111, D05301, doi:10.1029/2005JD005873.

Pavelin, E. G., C. E. Johnson, S. Rughooputh, and R. Toumi, 1999: Evaluation of pre-industrial surface ozone measure- ments made using Schonbein's method. Atmos. Environ., 33, 919-929.

Prather, M., and Coauthors, 2003: Fresh air in the 21st century? Geophys. Res. Lett., 30, 1100, doi:10.1029/2002GL016285.

Price, C., and D. Rind, 1993: What determines the cloud-toground lightning fraction in thunderstorms? Geophys. Res. Lett., 20, 463-466.

— change on global lightning distributions and frequencies. $J$. Geophys. Res., 99 (D5), 10 823-10 832.

Rasch, P. J., N. M. Mahowald, and B. E. Eaton, 1997: Representations of transport, convection and the hydrologic cycle in chemical transport models: Implications for the modeling of short lived and soluble species. J. Geophys. Res., 102, 28127 28138

Rind, D., J. Lerner, and C. McLinden, 2001: Changes of tracer distribution in the doubled $\mathrm{CO}_{2}$ climate. J. Geophys. Res., 106, $28061-28079$.

Roeckner, E., and Coauthors, 2003: The atmospheric general circulation model ECHAM5. Part I: Model description. Rep. 349, Max Planck Institute for Meteorology, Hamburg, Germany, $349 \mathrm{pp}$.

— horizontal and vertical resolution in the ECHAM5 atmosphere model. J. Climate, 19, 3771-3791.

Sanderson, M. G., C. D. Jones, W. J. Collins, C. E. Johnson, and R. G. Derwent, 2003: Effect of climate change on isoprene emissions and surface ozone levels. Geophys. Res. Lett., 30, 1936, doi:10.1029/2003GL017642.

Shallcross, D. E., and P. S. Monks, 2000: New directions: AQ role for isoprene in biosphere-climate-chemistry feedbacks. Atmos. Environ., 34, 1659-1660.

Shindell, D. T., G. A. Schmidt, R. L. Miller, and D. Rind, 2001: Northern Hemisphere winter climate response to greenhouse gas, ozone, solar, and volcanic forcing. J. Geophys. Res., 106, 7193-7210.

_- G. Faluvegi, and N. Bell, 2003: Pre-industrial-to-present-day radiative forcing by tropopsheric ozone from improved simulations with the GISS chemistry-climate GCM. Atmos. Chem. Phys., 3, 1675-1702.

Stevenson, D. S., C. E. Johnson, W. J. Collins, R. G. Derwent K. P. Shine, and J. M. Edwards, 1998: Evolution of tropospheric ozone radiative forcing. Geophys. Res. Lett., 25, 38193822 .

Edwards, 2000: Future estimates of tropospheric ozone radiative forcing and methane turnover-The impact of climate change. Geophys. Res. Lett., 27, 2073-2076

- R. Doherty, M. Sanderson, C. Johnson, B. Collins, and D. Derwent, 2005: Impacts of climate change and variability on tropopsheric ozone and its precursors. Faraday Discuss., 130, $1-17$.

Stocks, B. J., and Coauthors, 1998: Climate change and forest fire potential in Russian and Canadian boreal forests. Climate Change, 38, 1-13.

Thompson, A. M., K. B. Hogan, and J. S. Hoffman, 1992: Methane reductions-Implications for global warming and atmospheric chemical change. Atmos. Environ., 26A, 2665-2668.

van Dorland, R., F. J. Dentener, and J. Lelieveld, 1997: Radiative forcing due to tropospheric ozone and sulfate aerosols. $J$. Geophys. Res., 102, 28 079-28 100.

Volz, A., and D. Kley, 1988: Evaluation of the Montsouris series 
of ozone measurements made in the nineteenth century. $\mathrm{Na}$ ture, 332, 240-242.

Wang, Y., and D. J. Jacob, 1998: Anthropogenic forcing on tropospheric $\mathrm{O}_{3}$ and $\mathrm{OH}$ since preindustrial times. J. Geophys. Res., 103, 10 757-10 768.

Yienger, J. J., and H. Levy II, 1995: Empirical model of global soil-biogenic NOx emissions. J. Geophys. Res., 100, $11447-$ 11464 .
Zeng, G., and J. A. Pyle, 2003: Changes in tropospheric ozone between 2000 and 2100 modeled in a chemistry-climate model. Geophys. Res. Lett., 30, 1392, doi:10.1029/ 2002GL016708.

Zhang, G. J., and N. A. McFarlane, 1995: Sensitivity of climate simulations to the parameterization of cumulus convection in the Canadian Climate Centre general circulation model. Atmos.-Ocean, 33, 407-446. 